\title{
Democracy of Climate and Climate for Democracy: the Evolution of Quadruple and Quintuple Helix Innovation Systems
}

\author{
Elias G. Carayannis ${ }^{1}$ - David F. J. Campbell ${ }^{2,3,4}$ \\ Received: 3 February 2021 / Accepted: 24 February 2021 / Published online: 15 April 2021 \\ (c) The Author(s) 2021
}

\begin{abstract}
Quadruple and Quintuple Helix innovation systems are based on democracy and ecology. Two propositions are here key: (1) without a democracy or knowledge democracy, the further advancement of knowledge and innovation are seriously constrained, so in that sense, knowledge and innovation evolution depend on democracy and knowledge democracy; (2) ecology and environmental protection represent a necessity and challenge for humanity, but they also act as drivers for further knowledge and innovation (this should lead to a win-win situation for ecology and innovation). Therefore, for an innovation system to be a Quadruple/Quintuple Helix innovation system, the political regime hosting these helixes needs to be democratic in essence, not just in form. The next stage in evolution of innovation systems may be that this also will require a "democracy of climate" (promoting a social, cultural, economic, and political "climate for democracy"), where democracies as innovation enablers are creating innovation that regard the ecology as a crucial driver for further innovation and for responsible innovation.
\end{abstract}

Keywords Climate for democracy · Democracy · Democracy as innovation enabler · Democracy of climate - Democracy 5.0 - Digital transformation · Helix trilogy · Industry 5.0 • Mode 3 knowledge production · Quadruple and Quintuple Helix innovation systems · Quality of democracy · Responsible innovation · Society 5.0 . Triple Helix

David F. J. Campbell

david.campbell@donau-uni.ac.at; david.campbell@univie.ac.at; david.campbell@aau.at

Extended author information available on the last page of the article 


\section{Introduction: Helices Development in Comparison}

\section{"Democracy and the Environment are Endangered Species"}

Elias G. Carayannis, Interview to Riconfigure EU Project, November 2019 (Carayannis, 2020) http://riconfigure.eu/publication/democracy-andthe-environment-are-endagered-species/

In his famous book, "The Structure of Scientific Revolutions," Thomas S. Kuhn (1962) emphasizes that there is an evolution of thoughts, with mutual influences, new stages of thinking, also a learning and a cross-learning of thoughts, where new thoughts are developing in reflection of existing intellectual structures and patterns. There also can be a co-evolution of different ideas, not only with a reciprocal coinfluencing but also with distinct evolutionary lines.

The focus of this analysis is on the development and evolution of Quadruple and Quintuple Helix innovation systems. This implies a comparative analysis and discussion on the Triple Helix, Quadruple Helix and Quintuple Helix innovation systems. The "A Short History of Triple Helix, and of the Quadruple and Quintuple Helix Innovation Systems" section provides a short historical overview, while the "The Quintuple Innovation Helix and Industry and Society 5.0" section focuses on Industry 5.0 and Society 5.0 (Carayannis et al., 2021a, b). In the "Conclusion" section, it is being emphasized that the Quadruple and Quintuple Helix are based on democracy and an ecological sensitivity. Here references are being made to a "democracy of climate," intended to create a (social, cultural, economic, and political) "climate for democracy."

\section{A Short History of Triple Helix, and of the Quadruple and Quintuple Helix Innovation Systems}

"Should the public perhaps be considered as a fourth strand to be added to the Triple Helix model? In our opinion, the conceptualization of the public as merely a fourth helix narrows the public into another private sphere, rather than seeing civil society as the foundation of the enterprise of innovation." (Leydesdorff \& Etzkowitz, 2003, p. 57).

"Several contributors raised the issue of a fourth or fifth helix and one author provocatively suggested that we could perhaps also develop a Triple Felix model ..." (Leydesdorff \& Etzkowitz, 2003, p. 59).

"Three helices are sufficiently complex to understand the social reproduction of the dynamics of innovation (Etzkowitz \& Leydesdorff, 2000; Leydesdorff \& Etzkowitz, 1998); the three institutional spheres can be identified in our type of society as industry, academia, and government." (Leydesdorff \& Etzkowitz, 2003, p. 60). 
According to a literature review, carried out by Yuzhuo Cai and Annina Lattu (2020), early key publications on the Triple Helix are as follows: Etzkowitz \& Leydesdorff, 1995, where the Triple Helix model on innovation was introduced and explained systematically, and Etzkowitz and Leydesdorff, 2000, where Triple Helix was explained comprehensively. In 2003, Leydesdorff and Etzkowitz discussed the possible option of adding a fourth helix to the Triple Helix model (Leydesdorff \& Etzkowitz, 2003, p. 57; see also Leydesdorff \& Etzkowitz, 1998). Around 2012, Leydesdorff finally introduced the so-called concept of the N-Tuple of Helices in an article published in the Journal of the Knowledge Economy, edited by Elias G. Carayannis (Leydersdorff, 2012). The main focus of the Triple Helix innovation model concentrates on government-university-industry relations (Etzkowitz \& Leydesdorff, 2000; Leydesdorff, 2012). In that respect, one could say, that the Triple Helix represents a basic model or a core model for a knowledge production and an innovation application; however, the emphasis is on the economy, or a knowledge economy (so the interpretation here) and not the type of regime (democracy vs autocracy).

Early pre-work for the Quadruple Helix dates as far back as already to the early 1990s onwards (Carayannis \& Maldifassi, 1992; Carayannis, 1994a, 1994b; Carayannis, 1998; Carayannis, 2001; Carayannis \& Gonzalez, 2003; Carayannis et al., 2003). The two co-creators of the "Quadruple and Quintuple Helix innovation systems" are Elias G. Carayannis \& David F. J. Campbell in, 2009 and 2010 respectively (Carayannis \& Campbell, 2009, 2010). The conceptual and theoretical work on the Quadruple and Quintuple Helix innovation systems is original work, which, from the beginning, is work that was or is being designed as a four-helix or fivehelix model, and this is something very different from being a fourth (or fifth) helix to a Triple Helix model. The first publication on the Quadruple Helix is Carayannis and Campbell (2009), and the first publication on the Quintuple Helix is Carayannis and Campbell (2010). Both of these are peer-reviewed article publications in journals, which are also represented in standard journal databases. One secondary (open access) article release soon after is Carayannis et al. (2012).

The Quadruple and Quintuple Helix innovation systems was, of course, not created in a vacuum, but reflected and discussed the intellectual narratives that existed at its time. Therefore, the Quadruple and Quintuple Helix innovation systems more fully contextualized the "Triple Helix" (for example, Etzkowitz \& Leydesdorff, 2000), the "Quattro Helix" (Danilda et al., 2009), but also the "Mode 2 of knowledge production" (Gibbons et al., 1994). Something which may be often overseen is the fact that the Quadruple Helix not only associates with the (later) created Quintuple Helix but also with the so-called concept of a "Mode 3 knowledge production" (Carayannis \& Campbell, 2006). The article release of 2009 (Carayannis and Campbell) also had as main title: "'Mode 3' and 'Quadruple Helix': Toward a 21st Century Fractal Innovation Ecosystem." The first academic work on "Mode 3," in terms of a way of a knowledge production, was a book chapter, released in 2006 (Carayannis \& Campbell, 2006). Consequently, the book of Carayannis and Campbell (2012) ${ }^{1}$ also has as title: "Mode 3

\footnotetext{
1 See: http://www.springer.com/cda/content/document/cda_downloaddocument/9781461420613-c1. pdf?SGWID=0-0-45-1263639-p174250662
} 
Knowledge Production in Quadruple Helix Innovation Systems. 21st-Century Democracy, Innovation, and Entrepreneurship for Development."

In general, universities and higher education institutions have three main functions: teaching and education, research (research and experimental development, R\&D) as well as what is called "third mission" or "third party" activities or outreach actions and initiatives, for example, innovation, democracy, and civic education (Campbell \& Carayannis, 2013b, p. 5). One question arising is as to whether, as to what degree and how the art universities are differing from the scientific universities (in the world of the sciences). Certainly, art universities emphasize the arts, and the arts are different from the sciences. Yet, even art universities themselves frequently refer to the sciences. Thus, art universities can help co-create and co-develop further skills and competences for the teaching of the sciences and the conducting of research in the sciences. The other major challenge for art universities is to undertake "artistic research" and "arts-based innovation." In doing so, art universities and higher education institutions are also closely linked with national innovation systems and multi-level innovation systems. This widens the interdisciplinary and transdisciplinary spectrum of higher education institutions. Artistic research complements art teaching in art universities (see also the analysis in Bast, 2013). Universities of the arts and universities of sciences can join forces, and these associations can suggest new organizational structures to encourage creativity (Campbell, 2013a). When asking what the purpose of the arts is, the traditional answer is inclined to refer to "aesthetics". However, the arts may also be considered to represent a manifestation of knowledge (see also Carayannis \& Campbell, 2015). See Fig. 1 for a graphical visualization of this.

Academic research, in a traditional interpretation in context of universities of the sciences, focuses on basic research, often framed in a structure of academic disciplines and without a specific interest in the practical use of knowledge and innovation. This model of university knowledge creation is being called "Mode 1" of knowledge production (Gibbons et al., 1994). Mode 1 appears to be compatible with linear models of innovation, which often are being referred back to Vannevar Bush (1945). The linear model of innovation asserts that there is first a basic research in a university environment. Gradually, this university research then diffuses out into society and the economy. It is then the economy and societies, taking up the discoveries and research results of the universities, and are transforming and developing these further to applications of new knowledge and to enable innovations. The intention here is to create finally economic and commercial successes in the markets outside of the higher education system. This linear innovation framework is characterized by a sequential "cause-effect" relationship, between basic research (knowledge production) and innovation (knowledge application).

The Mode 2 (of knowledge production) emphasizes a knowledge application for the purpose of a problem-solving, and incorporates and promotes the following principles: "knowledge production in an application context," "transdisciplinarity," "heterogeneity and organizational diversity," "social responsibility and reflexivity," and "quality control" (see also Nowotny et al., 2001, 2003 and 2006, as well as furthermore Carayannis et al., 2017). In this context, the priority is to place an emphasis on the production of a knowledge for practical purposes. Mode 
Dimension of "traditional" understanding of art and arts: the "aesthetic" dimension of arts.

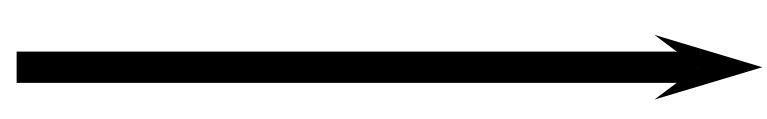

Aesthetic dimension of arts.

Additional dimension of art and arts: arts as a manifestation of knowledge.

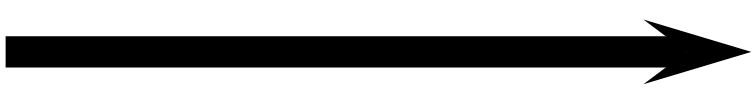

Knowledge dimension of arts.

Other additional dimensions of art and arts: further possible dimensions of arts.

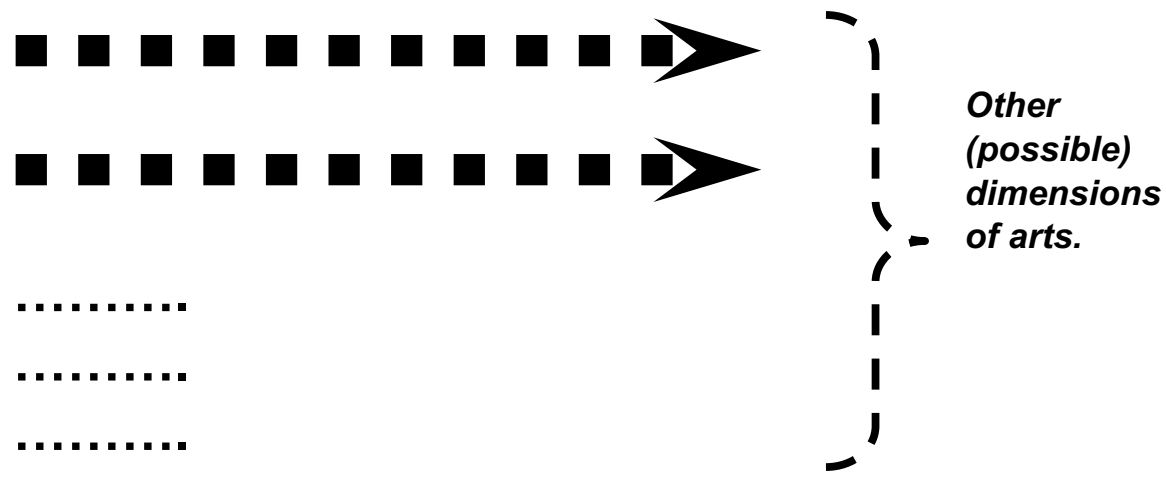

Source: Authors' own conceptualization and adopted from Carayannis and Campbell (2009; 2014, p. 9).

Fig. 1 Dimensions of conceptualization and measurement of art and arts

2 describes and encourages the use of clear references to innovation and innovation models. The linear model of innovation has also been challenged by nonlinear models of innovation, which are interested and designed in making more direct connections between knowledge production and knowledge application. In 
these nonlinear models, basic research and innovation are not seen as successive steps, but as parallel and equally important steps. Mode 2 therefore appears to be compatible with nonlinear innovation models and their ramifications.

The Triple Helix model of knowledge and innovation, with its particular relationship of academia, industry, and government, was proposed and introduced by Henry Etzkowitz and Loet Leydesdorff (2000, pp. 111-112). This approach is based on a knowledge and innovation production model, where three helices are interconnected and mutually referring to each other, thus shaping and creating a national innovation system. These three helices represent the following systems or sectors: academia (universities or higher education institutes), industry (business), and the state (government).

When Etzkowitz and Leydesdorff approach this theme of university, industry and government relationships and networks, they emphasize "trilateral networks and hybrid organizations," where the helices are inter-connected with each other in a hybrid fashion. According to Etzkowitz and Leydesdorff (2000, p. 118), the Triple Helix model provides a model, which describes Mode 2 as a phenomenon of shift in scientific knowledge production, whereas the Triple Helix could be interpreted to represent the societal superstructure on top of the knowledge production or the knowledge production shift (being postulated here). "[The] Triple Helix overlay provides a model at the level of social structure for the explanation of Mode 2 as an historically emerging structure for the production of scientific knowledge, and its relation to Mode 1." More recently, Leydesdorff (2012) even introduced the "N-Tuple Helix" model (Park, 2014).

Mode 1 and Mode 2 also can be interpreted as "knowledge paradigms," on which the knowledge production (and to some extent also the knowledge application) is based in universities and other higher education institutions. In accordance with Mode 1, quality and success may be defined in the following way: "academic excellence, which is a comprehensive explanation of the world (and of society) on the basis of 'basic principles' or 'first principles', as is being judged by knowledge producer communities (academic communities structured according to a disciplinary framed peer review system)." For Mode 2, quality and success are: "problem-solving, which is a useful (efficient, effective) problem-solving for the world (and for society), as is being judged by knowledge producer and knowledge user communities" (Campbell \& Carayannis, 2013b, p. 32; see also Campbell \& Carayannis, 2013a, 2013c, 2016a and 2016b).

A "Mode 3" type university or higher education institution would represent (and does represent) a type of organization or system that seeks creative ways to combine and integrate different principles of knowledge production and knowledge application (for example, as has been exemplified by Mode 1 and 2), while, at the same time, encouraging diversity and heterogeneity. This also should create creative and innovative contexts for research and innovation in organizations. Therefore, Mode 3 clearly promotes "creative knowledge environments" (Hemlin et al., 2004).

Universities or higher education institutions of a "Mode 3" type of system are designed to enable a "basic research in the context of application" (Campbell \& Carayannis, 2013b, p. 34). This aligns with qualities of nonlinear innovation. Governance decisions in or on higher education should be based on an understanding and sensitivity to the particular Mode in which the organization operates, either (for example) Mode 1, Mode 2, or Mode 3. The concept of "epistemic governance" emphasizes that 
the knowledge conceptions underlying knowledge production and knowledge application (innovation) are addressed with strategies, policies and measures that ensure quality and continuous quality improvement (Campbell \& Carayannis, 2013b, 2013c). Epistemic governance is referring explicitly to the "underlying understandings" that are underlying the structures and processes of an organization. Related to this is the proposed Fractal Education, Innovation and Entrepreneurship (FREIE) organizational governance design (Carayannis \& Campbell, 2011).

The competitiveness and superiority of a knowledge system or the degree of development of a knowledge system are particularly determined by their adaptive capability and capacity to combine and integrate several and different modes of knowledge and innovation through co-evolution, co-specialization and "co-opetition" (cooperation and competition), also of stock-and-flow dynamics (see Carayannis \& Campbell, 2009, p. 201; in relation to "co-opetition," see Brandenburger \& Nalebuff, 1997). Analogies are drawn and a common development is suggested between diversity and heterogeneity in advanced knowledge societies and knowledge economies as well as the political pluralism in a democracy (knowledge democracy) as well as the quality of democracy or of a knowledge democracy. The "democracy of knowledge" refers to this overlap and co-relationship.

Thus, "The Democracy of Knowledge, as a concept and metaphor, highlights and underscores parallel processes between political pluralism in advanced democracy, and knowledge and innovation heterogeneity and diversity in advanced economy and society. Here, we may observe a hybrid overlapping between the knowledge economy, knowledge society and knowledge democracy" (Carayannis \& Campbell, 2012 , p. 55). Therefore, the idea of "Knowledge Democracy" goes beyond that of the "Republic of Science" (Michael Polanyi, 1962) and is also related to the concept of the democratization of innovation (von Hippel, 1995, 2005).

The Triple Helix model emphasizes the relationship between academia, industry, and government (Etzkowitz \& Leydesdorff, 2000). In this regard, it is a basic or a core model for explaining knowledge production and knowledge application. Contrary to this, the models of innovation systems based on the Quadruple Helix and the Quintuple Helix are designed in such a way that they already understand and refer to a wider complexity and context of knowledge production and knowledge application (innovation). In this way, they are organically and proactively including and engaging civil society and environmental considerations. The analytical architecture of these models is therefore conceptualized on a broader basis. We can say metaphorically that the Quadruple Helix integrates and contextualizes the Triple Helix, while the Quintuple Helix integrates and contextualizes the Quadruple Helix (and the Triple Helix) (see Fig. 9 later on). The Quadruple Helix adds as a fourth helix citizens influenced by the media and culture ("media-based and culture-based public"), "civil society," as well as "art, arts, artistic research and arts-based innovation" but also democracy and knowledge democracy, all in all creators, inventors, innovators, and entrepreneurs. The Quadruple Helix innovation model can be seen as a model that integrates the dimension of democracy or the context of democracy in order to promote knowledge, knowledge production, and innovation (Carayannis \& Campbell, 2009, 2012, p. 14; Carayannis \& Pirzadeh, 2014; Campbell \& Carayannis, 2016b; see also: Bast et al., 2015; Danilda et al., 2009; Eigelsreiter, 2017; Mitterlehner, 2014; Galan et al., 2018; Schallmo et al., 2017). The 
innovation model of the Quintuple Helix is more complete in terms of its analytical and explanatory scope as well as in its design by adding additionally a fifth helix and perspective, which is "the natural environment of society" ("natural environments of society”). (Carayannis \& Campbell, 2010, p. 62; Carayannis et al., 2012; Carayannis et al., 2018a, 2018b).

The Triple Helix is explicit in recognizing the importance of higher education, when it comes to innovation. However, one could argue that the Triple Helix sees knowledge production and innovation in a direct relation with the economy, and, therefore, the Triple Helix mainly considers economics and economic activity. In this sense, the Triple Helix frames the knowledge economy. The Quadruple Helix brings a new perspective about society and democracy. The Quadruple innovation system underlines the fact that a sustainable development of the economy and in the economy (the knowledge economy) requires that there is a common development of the knowledge economy, knowledge society and of the knowledge democracy all together (see also section on Industry 5.0 and Society 5.0 later on). The Quadruple Helix even promotes the perspectives of the knowledge society and knowledge democracy to support, strengthen and advance knowledge production (research) and knowledge application (innovation). Moreover, the Quadruple Helix is explicit that not only scientific universities (or other higher education institutions in the sciences) but also art universities (or other higher education institutions in the arts) must be seen as decisive and determining institutions for the further advancement of knowledge and innovation systems: this enables and encourages interdisciplinarity and transdisciplinarity that allows for a mutual and mutually integrating networking of the arts and sciences so to create an essential and creative mixture to encourage and reinforce innovation. This is where the keys to future success lie. The concept of "social ecology" refers to the interactions between society and nature ("society-nature interactions"), which is to say between "human society" and the "material world" (see, for example, Fischer-Kowalski \& Haberl, 2007). The European Commission (2009) has identified the need for a socio-ecological transition of the economy and society as one of the greatest challenges ahead. It also recognizes that this is an opportunity for the future progress and for the advancement of the knowledge economy and the knowledge society and democracy. The Quintuple Helix refers to this socio-ecological transition of society, economy and democracy. This is the reason why the innovation system of the Quintuple Helix is designed so to be ecologically sensitive.

The Quintuple Helix innovation system bases its conception of knowledge production and knowledge application on social ecology. Environmental problems (such as global warming) represent matters of concern and survival issues for humanity and human civilization. The Quintuple Helix, however, sees and interprets environmental and ecological problems also as possible opportunities by identifying them as possible drivers for the production of future knowledge and the creation of future innovations (Carayannis et al., 2012). Finally, this refers to learning processes for the knowledge economy: "The Quintuple Helix supports here the formation of a win-win situation between ecology, knowledge and innovation, creating synergies between economy, society and democracy" (Carayannis et al., 2012, p. 1). 


\section{The Quintuple Innovation Helix and Industry and Society $\mathbf{5 . 0}$}

The five dimensions of the Quintuple Innovation Helix clearly qualify to relate to themes of Industry 5.0 and Society 5.0, which are which are manifestations of institutional, cultural, legal, social, political, economic and technological embodiments of the nexus of the government, university, industry, civil society, and environmental dimensions (see also Carayannis et al., 2020).

\section{Digital Transformation}

In the recent years, digital transformation (DT) has received a growing attention both by academics and practitioners; however, despite numerous scholars that have addressed this topic, a reconciled definition of DT is still missing (Morakanyane et al., 2017). One of the main reasons could lie in the fact that DT understanding requires an interdisciplinary approach (Hauseberg et al., 2019). Hausberg et al. (2019) highlight that although several works are focused on the technological aspects of this transformation, the "human" component is fundamental as well. Therefore, on the one hand, there are those studies that consider technology as the main driver of this "radical change" ( Nambisan et al., 2019), on the other side, there are those who describe digital technologies as an enabling factor for a new organizational shift (Morakanyane et al., 2017; Nambisan et al., 2019) and have also an impact on society, people as well as on the knowledge management (Braganza et al., 2017; Urbinati et al., 2018). On their in-depth literature review about DT Hausberg et al., 2019 have found that big data is the research stream with most contributions and the artificial intelligence and machine learning are those technologies that have a significant presence. Moreover, among the several research streams identified by authors, one was named "society"; it consists of works that deal with the role of digital technologies in the following issues:

Society and communication (Carolan, 2017; Gano, 2015; Madsen et al., 2016)

Policy and international (Chandler, 2015; Rothe, 2017)

Philosophy and ethics (Lake, 2017)

Thus, this stream, particularly relevant for our study, is characterized by a multidisciplinary approach that takes into account the DT from a societal perspective, with a particular focus on not only the opportunities but also risks connected to the big data and digital technology adoption.

\section{The Concept of Industry 4.0 in Review}

Digitalization has completely changed the world of industry, determining what today is called the fourth industrial revolution, better known as the phenomenon of "Industry 4.0." The term "Industrie 4.0" first appeared in a German strategic initiative in 2011 as a part of its high-tech program, and it was defined in the work of Kagermann et al. (2013, pp. 5) as "a new type of industrialization." If the first three industrial revolutions were the result of mechanization, electricity, and IT, the fourth come with the introduction of the Internet of Things and Services 
into the manufacturing environment. The economic impact of this revolution has a great potential, as it promises increased operational effectiveness as well as the development of entirely new business models, services, and products.

Currently, there is no consensus in the literature about the definition of Industry 4.0 (Hoffmann \& Rüsch, 2017) even if its implementation is at the center of the academic and political interest. Starting from the cited "High-Tech Strategy 2020" promoted by Germany, which provided for the annual allocation of millions of euros for the development of highly innovative and cutting edge technologies in the production field, many other governments begun to promote different initiatives and actions at a national level to favor the adoption of Industry 4.0 technologies by firms (Liao et al., 2017). Among them, the Advanced Manufacturing Partnership (AMP) promoted by the US government in 2011, the "Nouvelle France Industrielle" in 2013, the long-term framework presented by the UK governments for its manufacturing sector called "The future of Manufacturing," and the "Piano Industria 4.0" designed for Italian companies investing in technological transformation (see Fig. 2).

One of the main difficulties in defining Industry 4.0 derives from the different labels (industrial Internet, Internet of things, smart factories, human-machine-cooperation, smart manufacturing) used to indicate the same phenomenon: the application of digi-

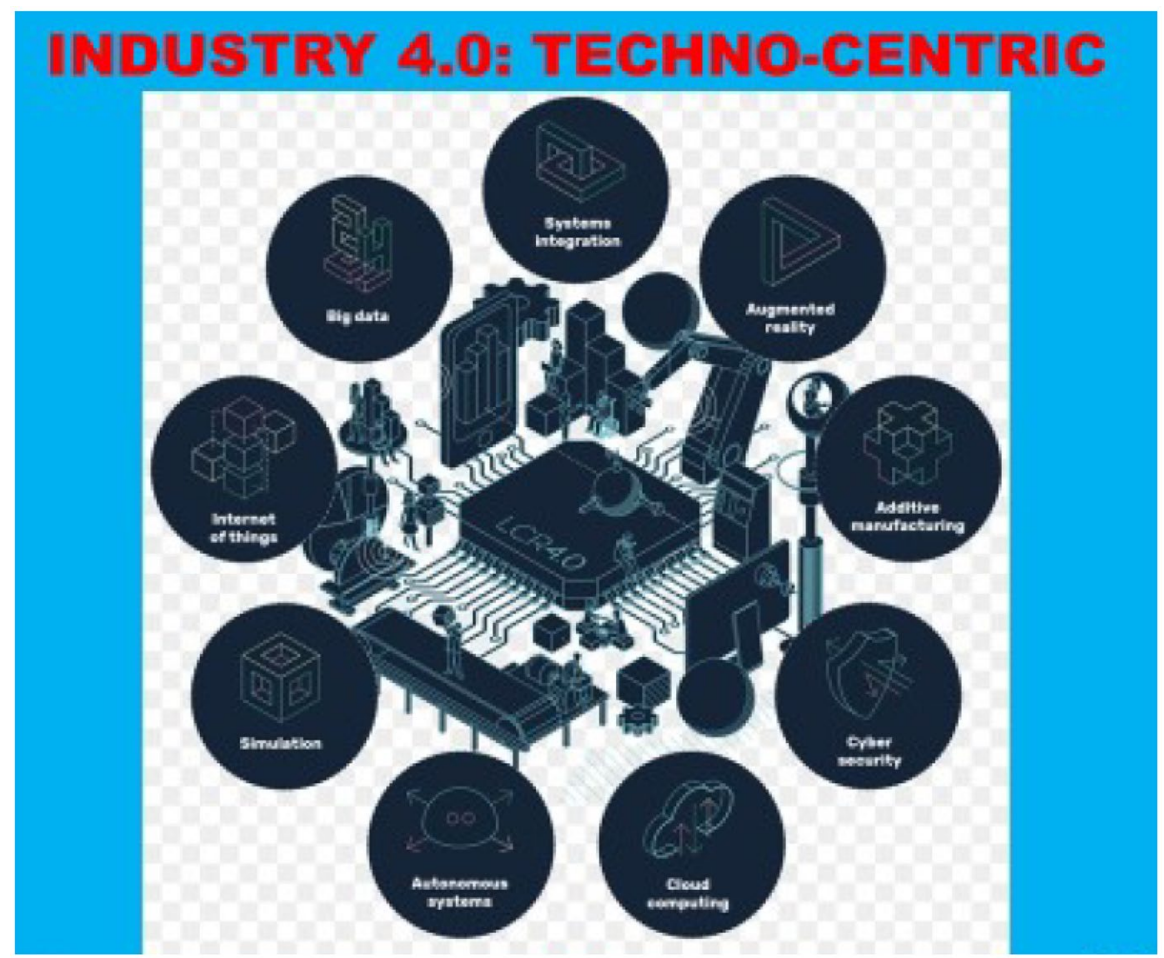

Fig. 2 Industry 4.0: techno-centric (Carayannis, 2019a, 2019b and 2019c; Carayannis \& Campbell, 2020) Source: Authors' own conceptualization, adapted from 
tal and interconnected technologies to the manufacturing sector. As Burrit and Christ (2016) claimed, Industry 4.0 is an umbrella term used to describe a group of connected technological advances that provide a foundation for increased digitization of the business. Hermann et al. (2015) identify four components of Industry 4.0: cyber-physical systems (CPS), Internet of things (IoT), Internet of services (IoS), and smart factory. CPS are systems that integrate computation, networking and physical processes (Bag et al., 2018); they actually bring the physical and the virtual world together (Hofmann and Rüsch, 2017). In the manufacturing environment, CPS comprise smart machines, storage systems, and production facilities able to autonomously exchange information, trigger actions, and control each other independently (Kagermann et al., 2013). The fact that machines and devices of production lines and cells are transformed into a network, allow to collect data in real-time and use them to make decisions such as prioritization of production orders, optimization of tasks, maintenance requirements, etc. (Lee \& Lee, 2015). Their application to manufacturing process allows for a whole new degree of control, transparency, efficiency, and flexibility of production processes. The IoT, or the Internet of everything (Lee \& Lee, 2015), was first described by Ashton (2009) as the phenomenon of adding new technologies (RFID) to everyday objects (Ashton, 2009). Today, the term has evolved in a much broader meaning, which includes a network of entities — which are called "Internet-connected constituent"—coupled to each other by any form of wireless sensors, actuators, mobile phones (Giusto et al., 2010). They allow the objects to provide information about their environment, context, and location (Ng, \& Wakenshaw, 2017). According to this meaning, even physical objects can now become "intelligent objects" with which it is possible to dialogue thanks to the Internet (Haller et al., 2008). Similar to IoT, the IoS allows service vendors to offer their services via the Internet and consequently to add value to their offer. New Web technologies, such as services-oriented architecture (SOA), software as a service (SaaS), or business process outsourcing (BPO), enabled the rise of new business models where "one party grants temporary access to the resources of another party in order to perform a prescribed function and a related benefit. Resources may be human workforce and skills, technical systems, information, consumables, land and others" (Hofmann \& Rüsch, 2017). As a result of application of IoT and IoS technologies in manufacturing, firms are shifting from offering products to offering integrated product-service bundles, a phenomenon that in literature is called "servitization" (see Fig. 3).

Furthermore, the combination of CPS, IoT, and IoS enables the birth of what is called "smart factories." Smart factory can be defined as a factory where CPS communicate over the IoT and IoS, assisting people and machines in the execution of their tasks (Hermann et al., 2015). In smart factories, human beings, machines, and resources communicate with each other as naturally as in a social network (Kagermann et al., 2013). By equipping manufacturing with sensors, actuators, and autonomous systems, Industry 4.0 will help factories in becoming more intelligent, flexible, and dynamic (Kamble et al., 2018). Beyond the aforementioned four components, different authors identified other technologies that can be considered under the umbrella term of Industry 4.0: cloud computing (Bag et al., 2018), additive manufacturing, wearables, big data, augmented reality applications, wireless network, smart cities. In particular, smart cities are cities that connect the physical, IT, social and business infrastructures in order to leverage the intelligence of the city's community (Hollands, 2008) and to support added-value services for citizens. For example, an impor- 


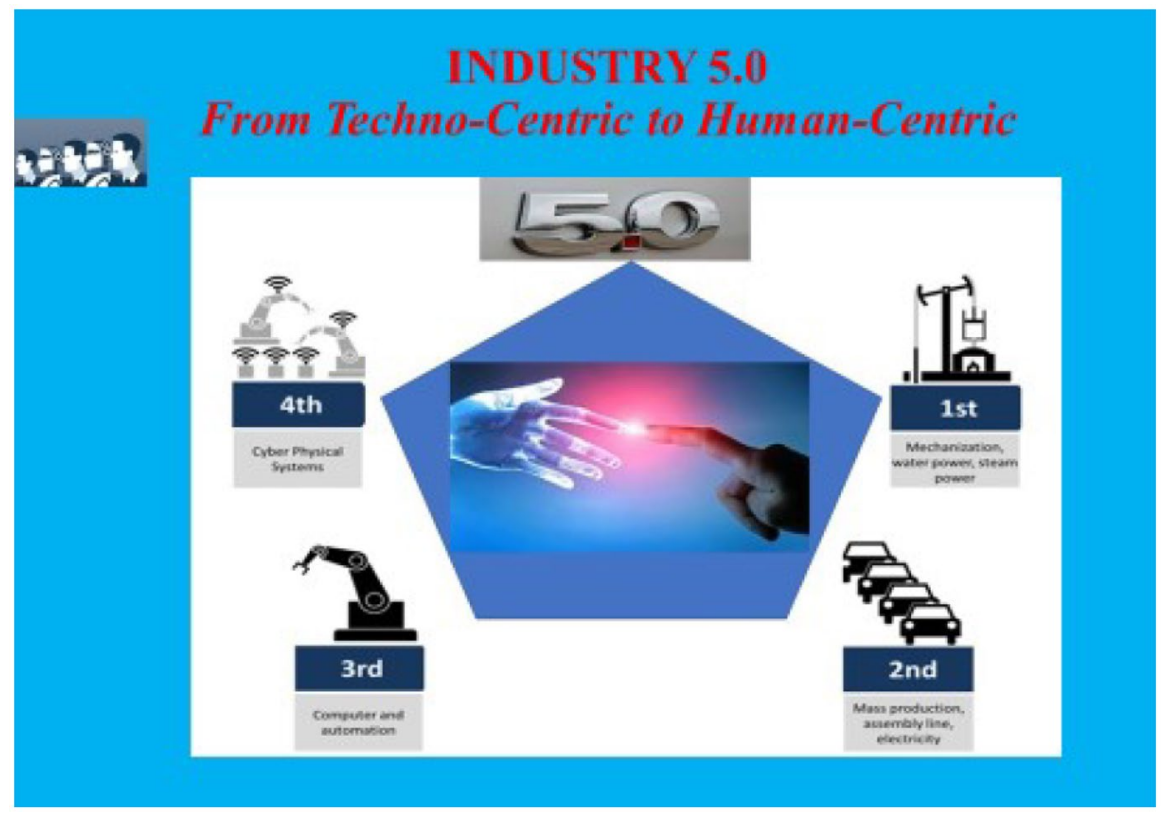

Fig. 3 Industry 5.0: from techno-centric to human-centric (Carayannis, 2019a, 2019b, and 2019c; Carayannis \& Campbell, 2020) Source: Authors' own conceptualization, adapted from

tant work of Martínez-Caro et al. (2018) acknowledges the importance of IoT for the wellbeing and social care. In doing so, they also give companies more opportunities to innovate through the use of IoT and CPS technologies (Bresciani et al., 2018).

Within Industry 4.0, a further element of complexity is its interdisciplinarity, since it touches different field such as engineering, computer technology, manufacturing, logistic, human resources, environmental science, consumer behavior, etc. As a consequence, as Piccarozzi et al. (2018, pp.16) pointed out in their literature review about Industry 4.0 in management studies, "the first insight that appear clear [...] is that Industry 4.0 is a cross-cutting theme of many disciplines that influence each other [...] It is very difficult to find a research paper purely dedicated to the managerial and business aspects of Industry 4.0 because in every aspects the business aspect blend with those pertaining to technical engineering, ICT or sustainability" (see Fig. 4).

Companies and societies are becoming increasingly aware of the benefits derived by the application of these new technologies as they allow to gain long-term competitiveness, to adapt more dynamically to customer changes and environmental requirements; to optimize decision-taking, resource productivity, and efficiency; and to create value opportunities through new services. However, some studies identified several factors that can either foster or hinder the adoption of Industry 4.0 by different organizations. For examples, Müller et al. (2018) identified three different opportunities which serve as antecedents: strategic opportunities (new business models, new value offers for enhanced competitiveness), operational opportunities (increased efficiency, decreasing costs, higher quality, increased speed and flex- 


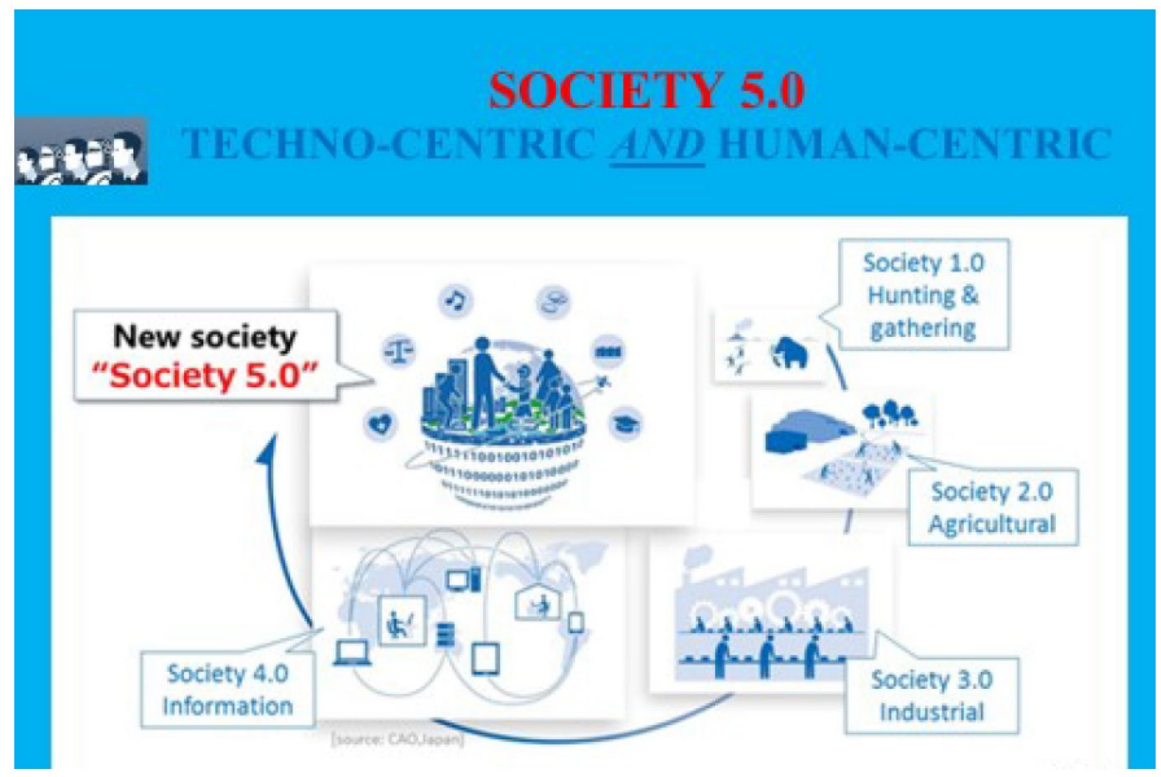

Fig. 4 Society 5.0: techno-centric and human-centric (Carayannis, 2019a, 2019b and 2019c; Carayannis \& Campbell, 2020) Source: Authors' own conceptualization, adapted from

ibility, load balancing, and stock reduction), environment and people opportunities (reduction of monotonous work, age-appropriate workplaces, reduction of environmental impact). On the other hand, they find three main barriers: competitiveness and future viability (existing business models endangered, loss of flexibility, standardization, transparency); organizational and production fit (high implementation efforts regarding costs and standardization); employee qualification and acceptance (employee fear and concerns, lack of expertise).

One of the main issues in Industry 4.0 concerns the role of human resources in the digital revolution (Horváth \& Szabó, 2019). On one side, new technology could actually increase labor shortages, reduce human work and allow firms and organizations to allocate human resources to higher value-added areas. On the other hand, digital revolution defined totally new disruptive paradigms requiring dynamic capabilities and the acquisition of knowledge and technology from outside the organization (Alavi \& Leidner, 2001; Carayannis et al., 2018b) (see Fig. 5).

Finally, among the many driving forces of sustainable practices, Industry 4.0 technologies are becoming more and more important since they can faster enable the development of green manufacturing processes, green manufacturing supply chain management, and also of green products (de Sousa Jabbour et al., 2018). 


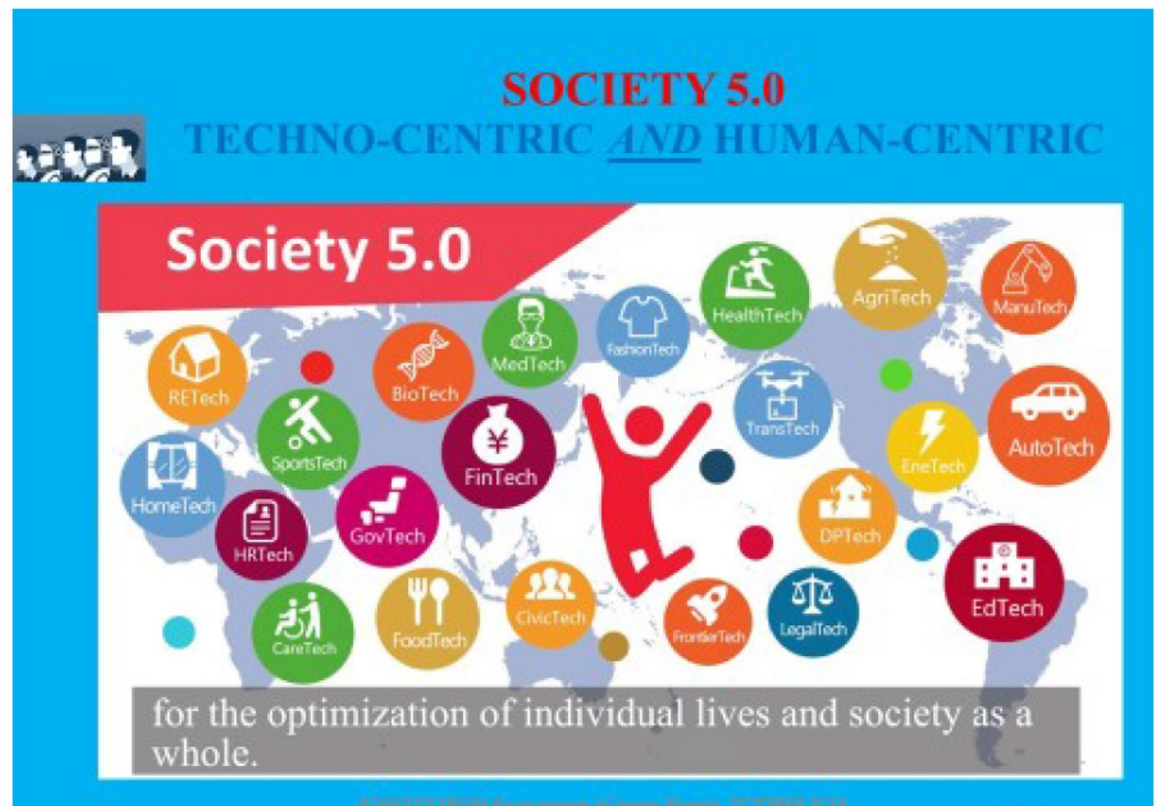

Fig. 5 Society 5.0: techno-centric and human-centric (Carayannis, 2019a, 2019b, and 2019c; Carayannis \& Campbell, 2020) Source: Authors' own conceptualization, adapted from

\section{Between Industry 5.0 and Society 5.0: a Parallel Path}

Industry 4.0 impacts the whole society, where society may also be understood as a broader ecosystem. Digitalization processes intend to optimize processes of industrial production (for example, supply of chain management, and the manufacturing and production in "smart factories"); at the same time, the digital transformation implies furthermore a reorganization of several "socio-cultural paradigms," which are expressing also relations to (and with) different technological innovations (Nambisan et al., 2019).

By referring to the concept of "Society 5.0," Carayannis, Draper and Bhaneja (2020, pp. 3-4) explain further:

"At the basis of this broadening, the idea of Society 5.0 (or "Super Smart Society") is defined. This prototypical philosophy originated in Japan and was presented as a core concept in the "Fifth Science and Technology Basic Plan" by the Japanese "Council for Science, Technology and Innovation", and approved by Cabinet decision in January 2016 (Ferreira \& Serpa, 2018; Salgues, 2018). It was identified as an overall growth strategy for Japan, and was reiterated in "The Investment for the Future Strategy 2017: Reform for Achieving Society 5.0". In essence, Society 5.0 tries to provide a common societal infrastructure for prosperity based on an advanced service platform. Industry 4.0 follows society 5.0 to a certain extent, but while Industry 4.0 focuses on produc- 
tion, Society 5.0 aims to put human beings at the center of innovation, taking advantage of the impact of technology and the results of industry 4.0 with the deepening of technological integration in improving quality of life, social responsibility and sustainability (Onday, 2019). This innovative perspective is not restricted to Japan, as it has points in common with those of the UNDP SDGs ("United Nations Development Program" "Sustainable Development Goals" (www.undp.org). .... Furthermore, unlike the concept of Industry 4.0, Society 5.0 is not constrained only to the manufacturing industry, but it solves social problems with the help of integration of physical and virtual spaces. In fact, Society 5.0 is the society where the advanced IT technologies already discussed (IoT, robots, artificial intelligence, augmented reality, etc.) are actively used in people common life, in the industry, health care and other spheres of activity not for the progress, but for the benefit and convenience of each person (Fukuyama, 2018)."

In a future era of Society 5.0, an emerging "post-nonclassical science of intersubjective management processes" may come together cybernetically with "Everget-

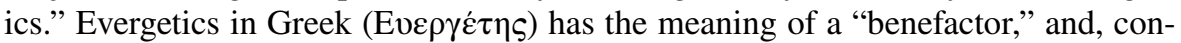
cerning its etymological origin, we already recognize a focus on "good actions" in processes of management and decision-making (Vittikh, 2014; Yousefikhah, 2017). Complementary to Society 5.0, there also should be a reference made to Industry 5.0, which could and should be framed in no less terms than a renewed "human centered/human centric industrial paradigm," which pushes for a re-organization of processes of production in industry (see further Lorenz et al., 2015).

As it is being stated in Carayannis, Draper and Bhaneja (2020, p. 3):

This is why the "... discussions on Industry 4.0 and Society have tended to focus on either a dystopian fearful future shaped by the IoT where robots ("CoBots") with AI replace humans, or a future that will invariably be benevolent and prosperous for all with the introduction of the Industry 4.0. Both visions subscribe, however, to technological determinism (evolution in organizational behavior, acceptance of robots in the workplace, evolution in organizational structures and workflows, evolution in work ethics, discrimination against robots or people, privacy and trust in a human-robot collaborative work environment, education and training, redesign of workplaces for robots), and as if the emergence of Industry 4.0 and its societal shaping and impacts are preordained and inevitable they do not yet acknowledge the need to broaden the understanding of Industry 4.0 outcomes and its multiple possible futures in society (Pashek et al., 2019; Pereira et al., 2020)."

In addition, Skobelev and Borovik (2017) formulate, if the main attention of an industrial revolution is dedicated to the technical/technological aspects of its implementation and the man, with his mental and creative abilities and his human touch, lies beyond this ideology, the only key that risks monopolizing the agenda of joint discussions is based on negative changes of labor market caused by the Industry 4.0 (Gehrke et al., 2015; Lorenz et al., 2015). This is why the central issues is "How can people and society benefit from Industry 4.0?" (Buhr, 2017). Hence, it is important 
that engineers and scientists improve their efforts in Innovation management by means of a new overall mindset guided by Design Thinking. In line with the concept of "absorptive capacity" (Zahara \& George, 2002), design thinking could be the answer to the wicked problem of innovation (Aslam et al., 2020; Buchanan, 1992; Pasisi et al., 2014). Stacey et al. (2000) and Dorst (2011) define the wicked problem as a complex and open-ended challenge and offer design thinking as a solution. Several scholars have emphasized the importance and role of design thinking for modifying the innovation management framework and creating an ecosystem for the IoT and Industry 5.0 era with a focus on human/user centeredness (Fauquex et al., 2015; Nahavandi, 2019; Taratukhin et al., 2018; Vitali et al., 2017; Walch \& Karagiannis, 2019). Similarly, Skobelev and Borovik (2017) and Ozdemir and Hekim (2018) discussed the role and importance of design thinking in Industry 5.0, which is more human-centered as compared to Industry 4.0. Design thinking helps to connect innovation and technological policy with the corporate strategy of the firm, thus creating a suitable environment and ecosystem for IoT and Industry 5.0. Organization for Economic cooperation and Development (OECD, 2005) first introduced the concept of "implement-ability" of innovation, which means that innovation should create value for its users and that if innovation is not creating any value or bringing any change in the lives of its users, then it cannot be regarded as true innovation. The concept of implement-ability of innovation puts the customer or user at the center of the whole innovation management process. Since the worker in a highly technologized and machine-assisted context would be "the user" of a reorganization of the work structure and measures; this involves finding the right configuration that would allow humans and machines to interact by incorporating various human characteristics in the original design at different levels. One of the best ways to accomplish this is by identifying the prevailing roles of each party. For instance, human beings are better at interactions, intuition, empathy, and complex decision making while machines excel at the identification of patterns, processing of data, calculations, and data search. The goals are that future machines and smart devices will improve human life and work (Elim \& Zahi, 2020; Ellitan \& Anatan, 2019; Riesener et al., 2019).

Definitively, there is a need for new interdisciplinary research between science and engineering with the aim of developing the perfect human-technology collaboration in Industry 5.0. In addition to this, it is necessary to develop and conduct a multilevel analysis, which takes into account three levels of framework: macro, meso, and micro. A smart industry must understand and update the situation inside and outside its boundaries, with a broad perspective of intraorganizational and interorganizational cooperation. In a business firm perspective, a micro level would concern the optimization of production processes and structure, with reference to the dynamics relating to worker-machine interaction and the implementation of new products and services closer to the needs expressed by customers (and stakeholders in general). At a meso level, we can assume an analysis of the industry in which the firm is located, also including the territorial peculiarities within which to develop cooperative synergies. Lastly, a macro analysis (completely external agents, such as political, economic, demographic, sociocultural conditions, legal aspects, technology, etc.) can be implemented to support joint growth based on the new routes of an industry fully declined 


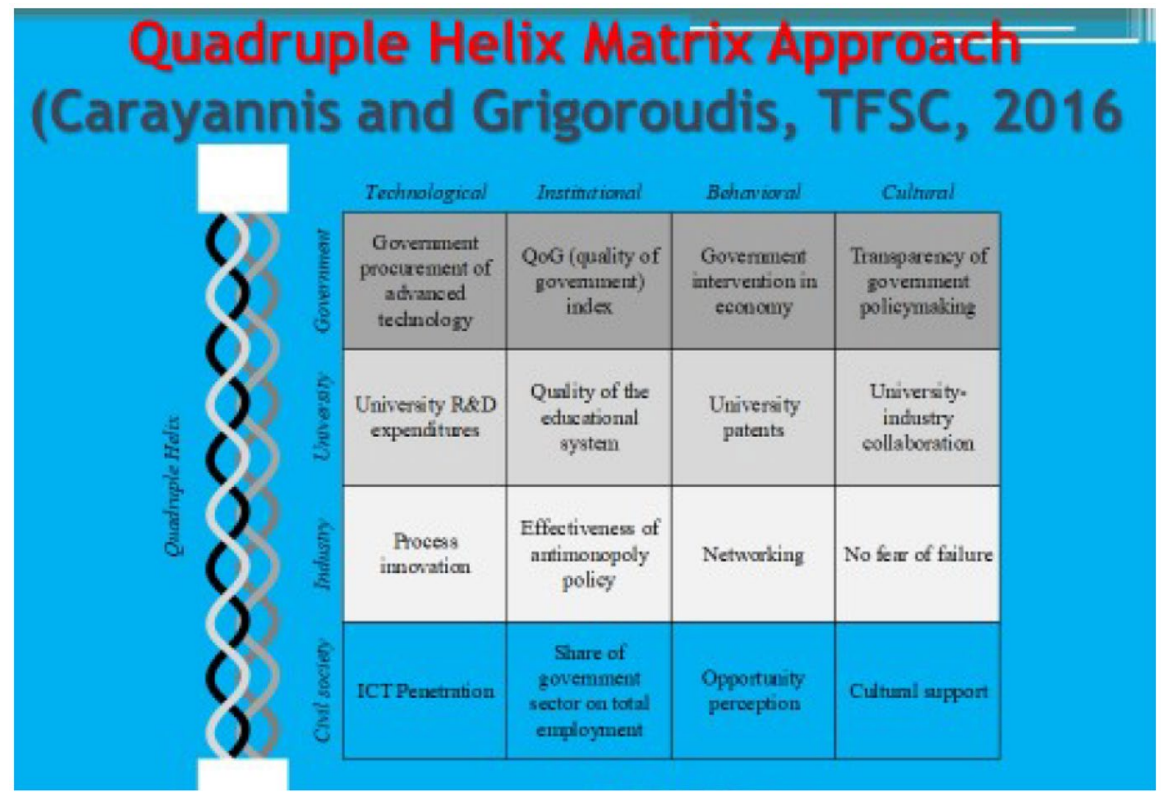

Fig. 6 Quadruple Helix matrix approach (Carayannis, 2019a, 2019b and 2019c; Carayannis and Campbell, 2020) Source: Authors' own conceptualization, adapted from

in terms of 5.0 version. This multi-level path is still very relevant to the condition of Industry 4.0 toward Industry 5.0/Society 5.0. Starting with a clear vision and mission statement, then translated into strategies and operational plans, it can ensure the sustainability of the firm and, in a synecdotal relationship, that one of its broader ecosystem, by taking into account all the Ethical, Legal, and Social Implications (ELSI) involved. Again, given the importance of the social aspects related to the concept of Industry 5.0, proposed a paradigm shift from cyber-physical systems (CPS) to cyber-physical-social systems (CPSS). The application of the (eco)logics that orbit around the quintuple helix innovation model (Carayannis \& Campbell, 2009, 2010) can ensure the continuous interaction of the five dimensions involved: (1) industry, (2) government, (3) university, (4) society, and (5) natural environment, going toward an innovation eco-system design centered on a truly human-centered, "evergetical," 5.0 paradigm (furthermore, see also Carayannis \& Campbell, 2019) (Fig. 6).

\section{Conclusion}

"Over the medium to long term, our fundamental belief and premise is that true and transparent democracy constitutes a sine qua non for smart, sustainable and inclusive growth and this constitutes our main motivation and guide for our focus on ways and means that concepts such as the Quadruple and Quintuple Innovation Helix, can better serve architect a better tomorrow for the peoples of the world." (Carayannis and Campbell in Park, 2014, p. 5). 
"The two endangered species of today: Democracy and Environment need a quadruple and quintuple innovation helix framework approach. The triple helix ennobles, empowers and enables autocratic policies and practices." (Carayannis, 2020, p. 4: http://riconfigure.eu/wp-content/uploads/2020/01/ Interview-with-Elias-Carayannis_2020_Final.pdf).

"We need to change the way we envision both business and society. The old ways have worn themselves out. We are having both a crisis of democracy and a climate crisis. They are both the result of a limited way of thinking."

(Carayannis, 2020, p. 3: http://riconfigure.eu/wp-content/uploads/2020/01/ Interview-with-Elias-Carayannis_2020_Final.pdf).

“... finally, as a last note and thought: perhaps the economic successes of nondemocracies or autocracies (authoritarian and semi-authoritarian regimes) are being overestimated anyway, because autocracies are also benefitting from the knowledge production and innovation systems of democracies and semi-democracies, so in that sense autocracy is depending on democracy and the knowledge and innovation of democracy in a global system." (Campbell, 2019, pp. 338-339: https://link.springer. com/chapter/10.1007/978-3-319-72529-1_7).

Again we want to refer to the main motivation of this analysis, which is the development and evolution of Quadruple and Quintuple Helix innovation systems, in reference to a "democracy of climate" (climate of democracy, climate for democracy), and the analytical research interest to systematically compare the Triple, Quadruple, and Quintuple Innovation Helices from a theory, policy, and practice set of perspectives. Therefore, in the following, the key features of Mode 3 knowledge production and the Quadruple and Quintuple Helix innovation systems again are summarized in a focused manner, finally referring to the innovation-guiding vision of democracy and ecology (see Fig. 7).

\section{Summary of the Mode 3 Knowledge Production}

Emphasizing again a more systemic perspective for the Mode 3 knowledge production, a focused conceptual definition therefore may be as follows (Carayannis \& Campbell, 2012, p. 49): Mode 3 “... allows and emphasizes the co-existence and co-evolution of different knowledge and innovation paradigms. In fact, a key hypothesis is, "the competitiveness and superiority of a knowledge system or the degree of advanced development of a knowledge system are highly determined by their adaptive capacity to combine and integrate different knowledge and innovation modes via co-evolution, co-specialization and co-opetition knowledge stock and flow dynamics" (see Carayannis \& Campbell, 2009; on "Co-Opetition," see Brandenburger \& Nalebuff, 1997). Analogies are being drawn and a co-evolution is being suggested between diversity and heterogeneity in advanced knowledge society and knowledge economy, and political pluralism in democracy (knowledge democracy), and the quality of a democracy or knowledge democracy. The "democracy of knowledge" refers explicitly to this overlapping relationship. As is being asserted, "The democracy of knowledge, as a concept and metaphor, highlights and underscores parallel processes between political pluralism in advanced democracy, and knowledge and innovation heterogeneity and diversity in advanced economy and 


\title{
Quintuple Helix: \\ Social Ecology, \\ Environment (Environments).
}

\section{Quadruple Helix: \\ Knowledge Society, \\ Knowledge Democracy.}

\author{
Triple Helix: \\ Knowledge Economy.
}

\begin{abstract}
Source: Authors' own visualization, see also Carayannis and Campbell (2009, p. 207; 2010, p. 62; 2014), Carayannis, Barth and Campbell (2012, p. 4), Etzkowitz and Leydesdorff (2000, p. 112) and Danilda et al. (2009).

Furthermore, see Galan, Campbell and Carayannis (2018, p. 65).
\end{abstract}

Fig. 7 The multi-level helix structure of innovation and innovation systems

society. Here, we may observe a hybrid overlapping between the knowledge economy, knowledge society and knowledge democracy" (Carayannis \& Campbell, 2012, p. 55).

There are different concepts and understandings of "learning". Elias G. Carayannis (2001) has suggested the existence of different levels of learning, asserting the three different forms of learning may be identified: (1) learning, (2) learning to learn, (3) and learning how to learn learning.

\section{Summary of the Quadruple and Quintuple Helix Innovation Systems}

The approaches of the Quadruple Helix and Quintuple Helix innovation systems are designed to comprehend already and to refer to an extended complexity in knowledge production and knowledge application (innovation); thus, the analytical architecture of these models is broader conceptualized. To use metaphoric terms, the Quadruple Helix transcends the Triple Helix, while the Quintuple Helix embeds and contextualizes the Quadruple Helix. The Quadruple Helix emphasizes as a fourth helix the "media-based and culture-based public," "civil society," "arts, artistic research and arts-based innovation," but also "democracy and knowledge democracy" (Carayannis \& Campbell, 2009, 2012, p. 14; Carayannis et al., 2012; Carayannis et al., 2018a, 2018b; see furthermore: Bast, Carayannis \& Campbell, 2015, 2019; Danilda et al., 2009; Park, 2014). Therefore, the Quadruple Helix also could be emphasized as the perspective that specifically brings in the "dimension of democracy" or the "context of democracy" for knowledge, knowledge production, knowledge application and innovation (Campbell, 2019, pp. 61, 343). The Quintuple Helix innovation model even is 
clearly more comprehensive in its analytical and explanatory stretch and reach, contributing the fifth helix (and perspective) of the "natural environments of society" (Carayannis \& Campbell, 2010, p. 62) (see Figs. 8 and 9).

For the Quadruple and Quintuple Helix innovation systems also the way how the higher education system and the firms (companies) are interacting and cooperating

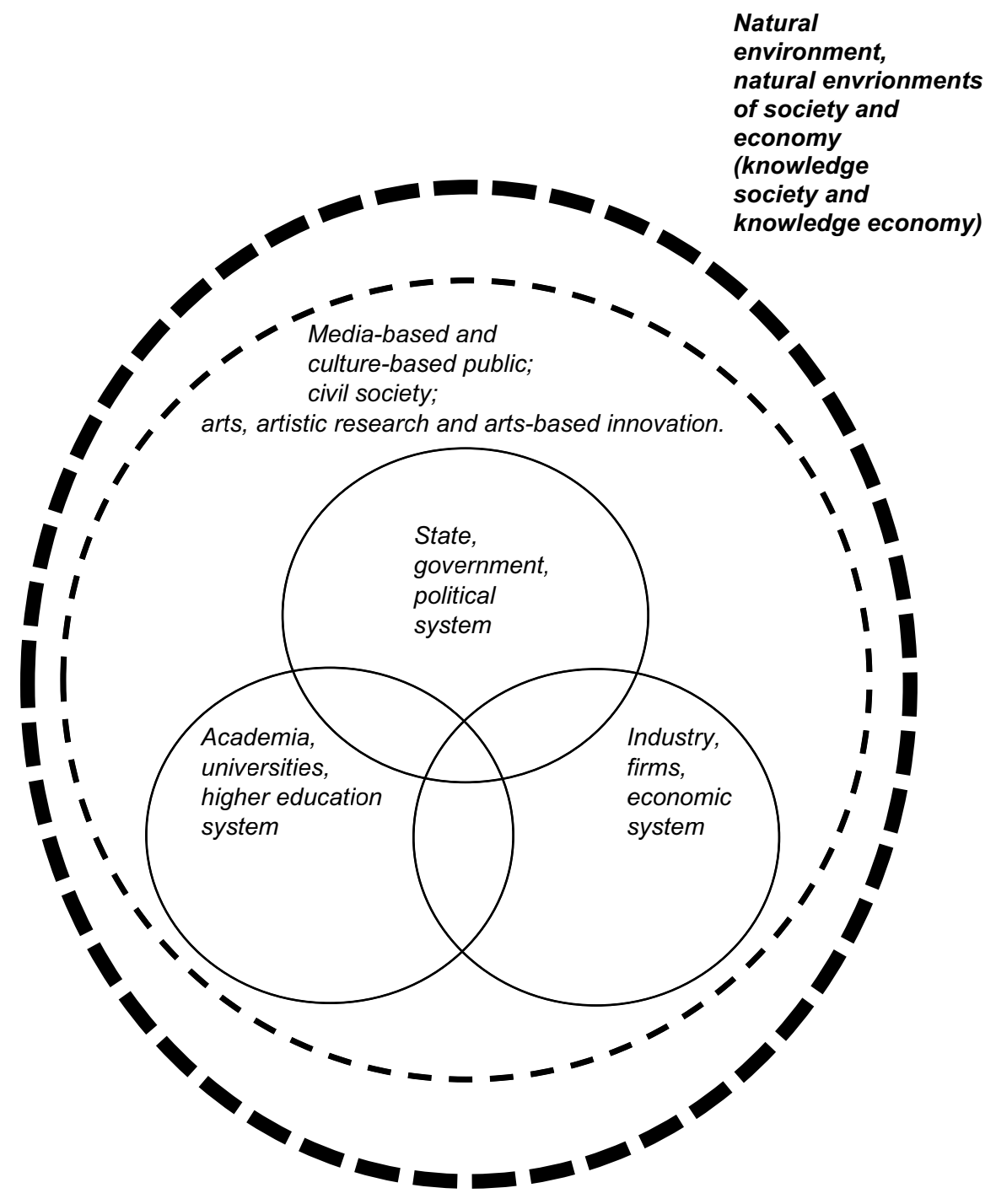

Source: Authors' own conceptualization and adapted from Carayannis and Campbell (2010, p. 62; 2013).

Fig. 8 The Quintuple Helix (five-helix model) innovation system 


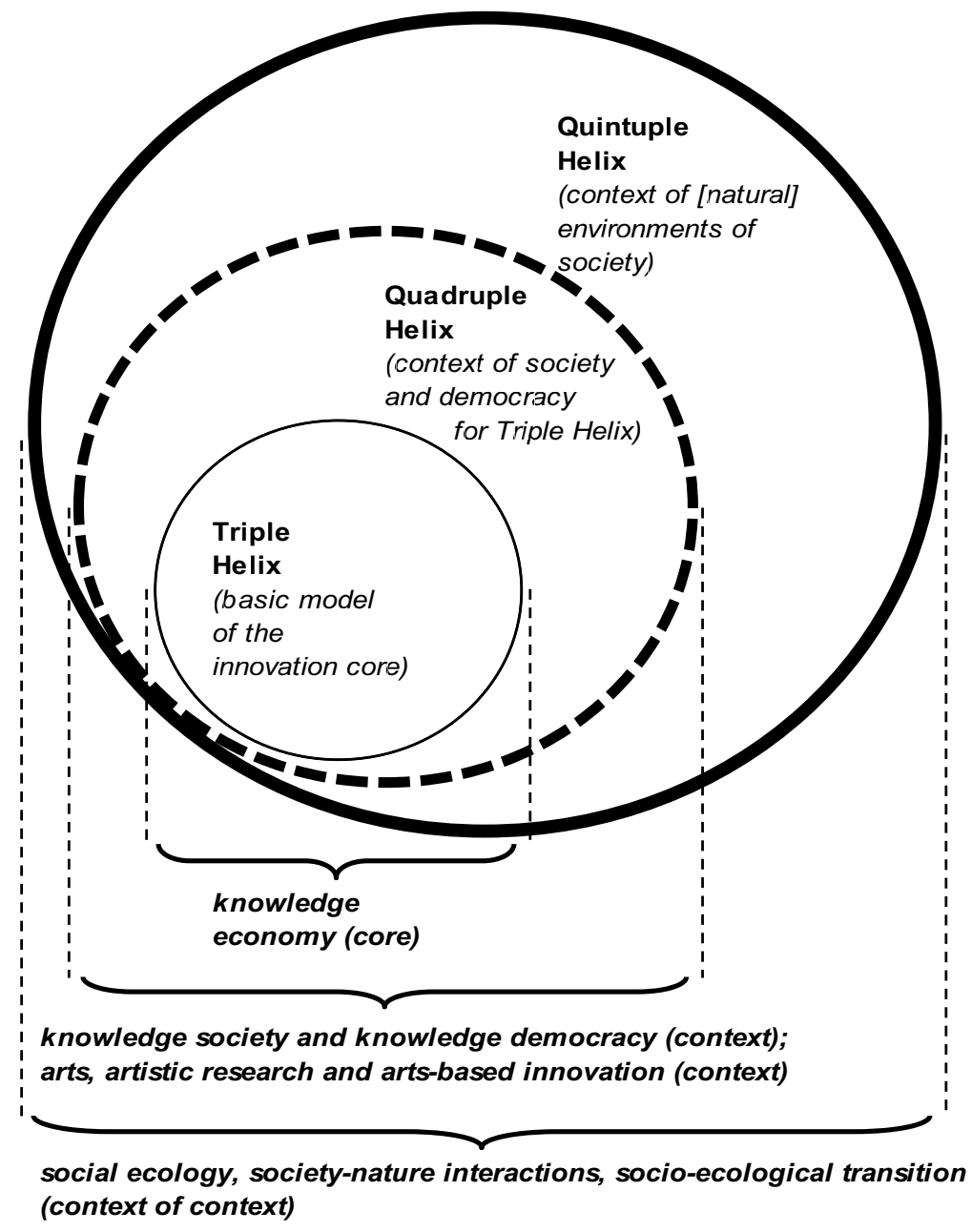

Source: Author's own conceptualization based on Carayannis and Campbell (2014, p. 15), and adapted from Carayannis and Campbell (2009, p. 207). Furthermore, see Carayannis, Barth and Campbell (2012, p. 4). See also Etzkowitz and Leydesdorff (2000).

Fig. 9 The Quadruple and Quintuple Helix innovation systems in relation to society, economy, democracy, and social ecology

is of importance. In general, there is the assumption that knowledge and innovation are becoming increasingly important for the economy, also basic research ("basic research in the context of application", Campbell \& Carayannis, 2013b, p. 34), also the creation of networks, supporting a co-evolution of higher education institutions and companies, enabling a co-evolution of the world of academia and the world of 
business, but where the qualities of good academia and the qualities of good business prevail. The concept of the "academic firm" aims to elaborate on such developments (Campbell \& Carayannis, 2016b). The academic firm (either as a whole firm or as a subunit of a firm) focuses on knowledge, knowledge creation, knowledge production and knowledge application, and regards these as sources for innovation. The academic firm is interested in engaging with higher education institutions in networks. Furthermore, the academic firm regards an "academic atmosphere" and "internal academic environments" as being essential for fostering knowledge and innovation. Figures 10 and 11 present these structures and processes in a visualized form.

\section{Democracy of Climate as Ultimate Outlook: Quadruple and Quintuple Helix Innovation Systems Are Based on Democracy and Ecology}

In a recent interview, Carayannis (2020) coined the following metaphor: "Democracy and the environment are endangered species." In a certain way, the contemporary world may be seen as an unfolding race or as a competition of "developed democracies versus emerging autocracies" (Carayannis \& Campbell, 2014). The concept and theory of the Quadruple and Quintuple Helix innovation systems is based on democracy and ecological sensitivity. "Democracy as innovation enabler" (Campbell, 2019) emphasizes a co-evolution of democracy (knowledge democracy) with knowledge and innovation (Campbell et al., 2015).

The approach of Quadruple and Quintuple Helix innovation systems provokes with the following two propositions:

1. Without a democracy or knowledge democracy, the further advancement of knowledge and innovation are seriously constrained. In this sense, knowledge and innovation evolution depend on democracy and knowledge democracy.

2. Ecology and environmental protection represent a necessity and challenge for humanity, but they also act as drivers for further knowledge and innovation (this should lead to a win-win situation for ecology and innovation).

For the Quadruple and Quintuple Helix innovation systems, democracy and ecology (environmental protection) are constituting categories, without these a Quadruple and Quintuple Helix innovation system not possible is. To elevate here to next levels, implications could be that climate (as a component and crucial category of ecology), so to say climate itself, is being integrated into understandings of democracy and quality of democracy. "Democracy of climate" (creating a "climate for democracy," desirably a "positive climate" for democracy), in cocreation with a "democracy of knowledge" (emphasizing a co-evolution of political pluralism and a diversity of knowledge modes in innovation), are referring to new designs and performances of innovation and innovation systems, being furthermore expressed in the principles, building blocks and design of Quadruple and Quintuple Helix innovation systems. Democracy enables and encourages innovation, and the ecology and climate can act as drivers for further innovation. 
Model of linear innovation modes:

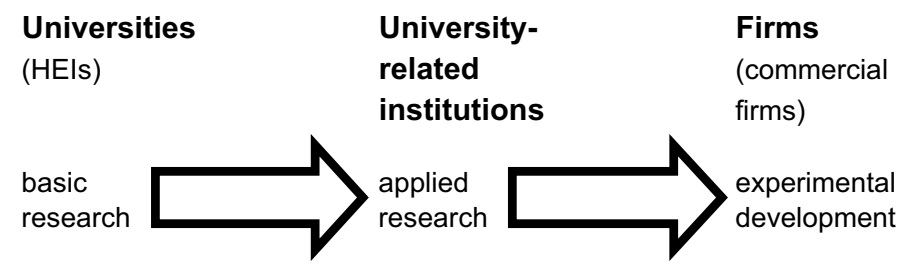

Model of non-linear innovation modes:

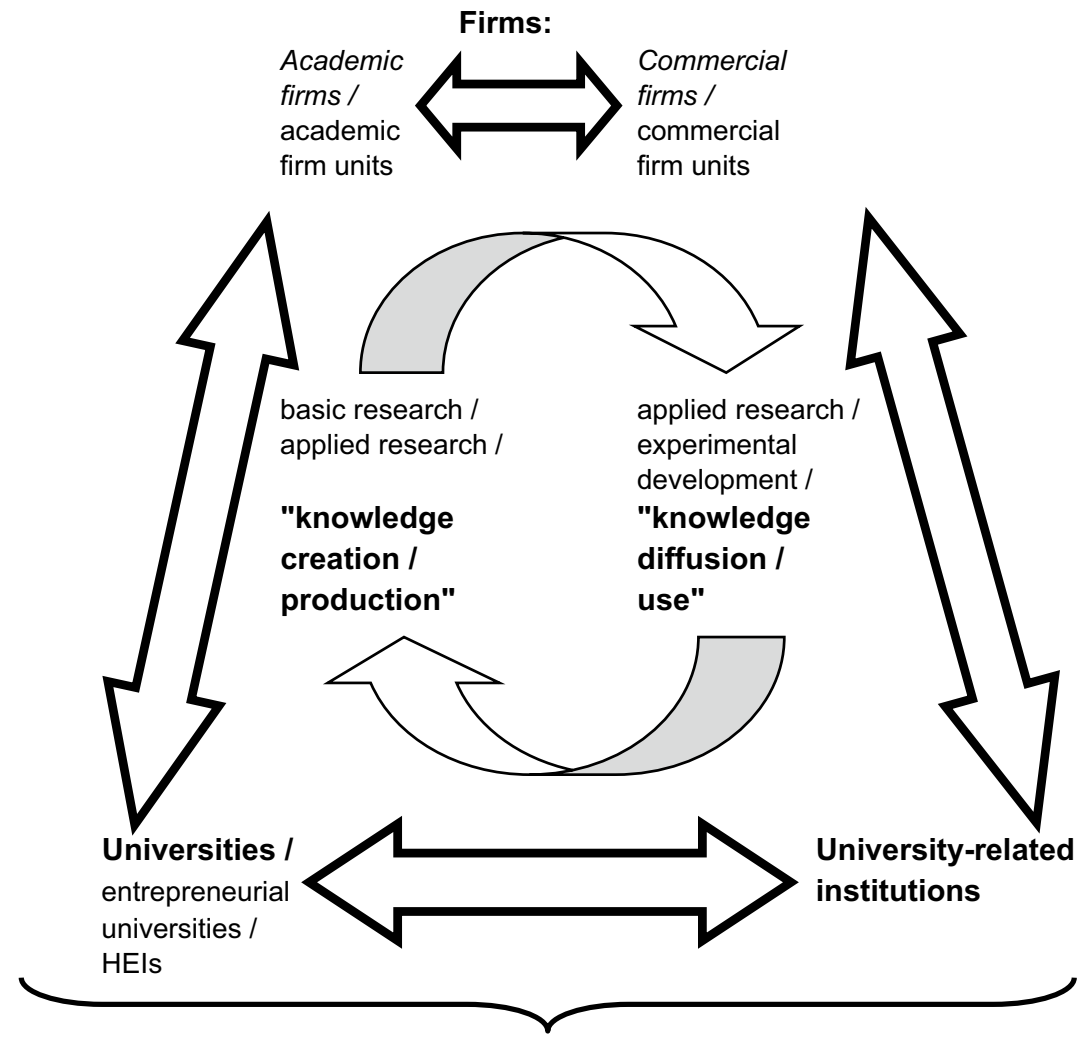

Mode 3 Innovation Ecosystem

Source: Authors' own conceptualization and adapted from Carayannis and Campbell (2009).

See also Campbell and Carayannis (2013a, p. 29; 2016a, p. 6).

Fig. 10 Linear and nonlinear innovation modes linking together universities with commercial and academic firms (firm units) 


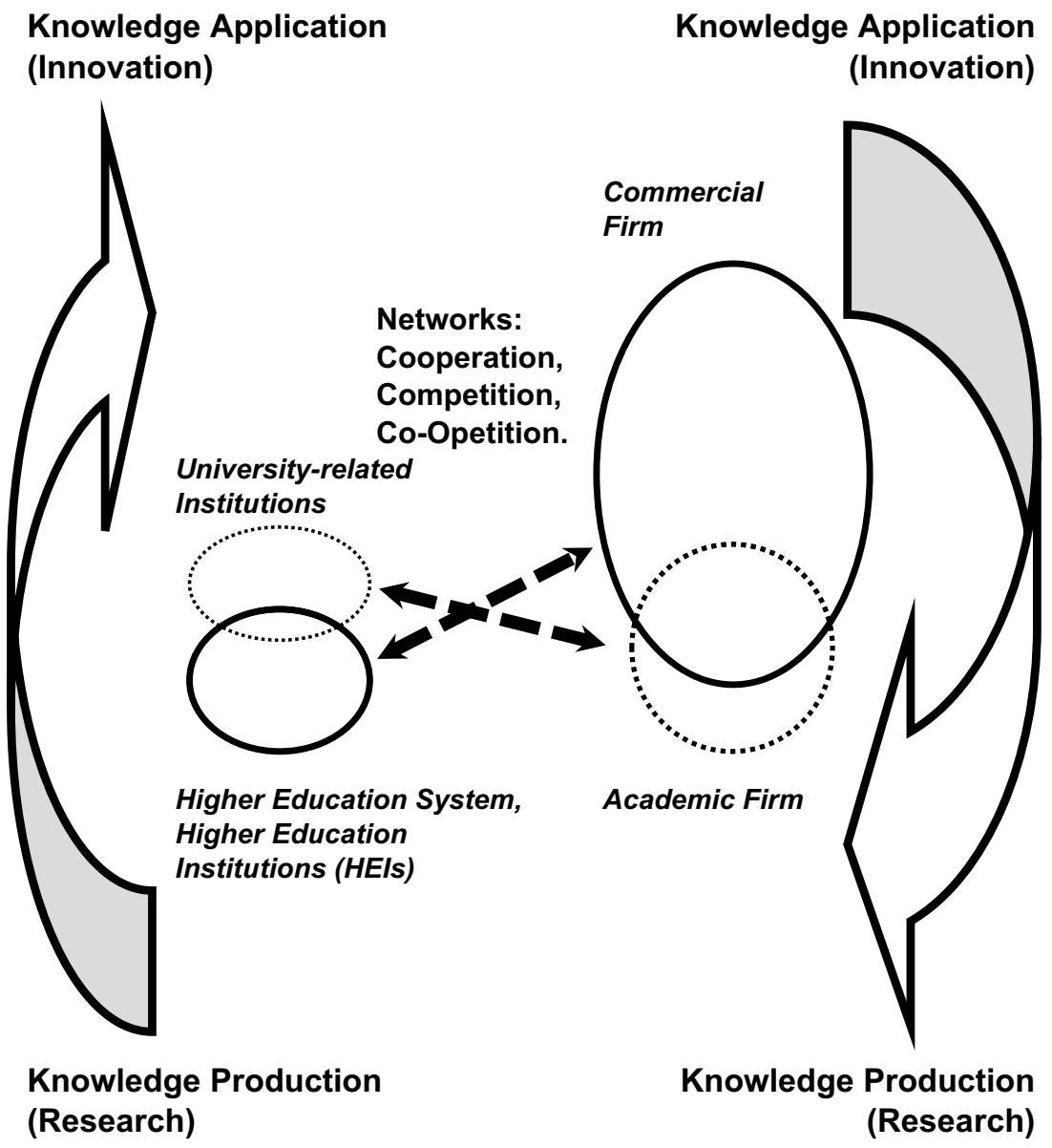

Source: Authors' own conceptualization based on Carayannis and Campbell (2009, p. 211; 2012, p. 25) and on Campbell and Carayannis (2013b, p. 29). Adapted from Campbell and Carayannis (2016b, p. 3).

Fig. 11 Knowledge production, linear and nonlinear innovation interaction between academic firms, commercial firms, and universities (higher education institutions)

"Democracy and climate change" (Hanusch, 2018) and "climate change and the future of democracy" (Deese, 2019) already are representing examples for academic research inquiry into such topics. These themes can be regarded as variations of "climate and democracy" or "democracy and climate." Ecology, ecological challenges (such as global warming), and environmental protection are essential for the survival, but more so the prosperous development of human civilization, at least on Earth and beyond (Carayannis \& Campbell, 2019). "Democracy of climate" (promoting a "climate of democracy", ideally also a social, cultural, economic, and political "climate for democracy") clearly advances and progresses here the conventional understanding, proposing further steps in the evolu- 
tion of innovation and innovation systems, where democracies as innovation enablers are creating innovation that regards the ecology as a crucial driver for further innovation and for responsible innovation. Through this, democracy, innovation, and ecology (climate) are being interwoven and are playing together, which should create sustainable development (Campbell, 2019).

The Triple Helix, which conceptual understanding does it have about democracy and ecology? Based on the two classical publications of Etzkowitz and Leydesdorff (2000, 2003), this is difficult to assess, because in Etkowitz and Leydesdorff (2000), democracy and ecology are not mentioned by word, and in Leydesdorff and Etzkowitz (2003) ecology is being not mentioned by word, democracy is mentioned, but only once, and only in reference to "technological democracy," and this in reference to Latour and Weibel (2002). The direct quote from Leydesdorff and Etzkowitz (2003, p. 57) is, "The axis governance/citizenship is in need of new forms of representation in a 'technological democracy' (Latour \& Weibel, 2002)." Furthermore, it should be added that in Etzkowitz and Leydesdorff (2000) and Leydesdorff and Etzkowitz (2003), also at no place there is the mentioning of the words or terms of "Quadruple" and "Quintuple." We should add that Leydesdorff published in 2012 his model of "N-Tuple of Helices." This could be interpreted as an (abstract) meta-reflection of different helices in innovation systems, by this also referring comparatively to already established helix models.

Indeed, the article of Leydesdorff and Etzkowitz (2003) had an interesting title: "Can 'The Public' be considered as a Fourth Helix in University-Industry-Government Relations?" However, Leydesdorff and Etzkowitz took the explicit decision of not to develop a fourth helix in addition to Triple Helix: "Three helices are sufficiently complex to understand the social reproduction of the dynamics of innovation ...; the three institutional spheres can be identified in our type of society as industry, academia, and government." (Leydesdorff \& Etzkowitz, 2003, p. 60).

Referring back to the approach of Kuhn (1962), the structure of scientific revolutions, could the history of ideas about innovation have developed differently, if back in 2003, in their published article, Leydesdorff and Etzkowitz (2003) had decided to add the development of a fourth helix to Triple Helix? Our answer is: yes, for sure.

As already has been elaborated by Campbell, Carayannis and Bast (2019, pp. 245-246): the "transformation of Industry 4.0 will destroy labor, and the transformation of Industry 4.0 will create new labor, so finally there even may more (new) labor (Bast et al., 2019). This requires, however, to reorganize labor and education in innovative and progressive approaches, so that then the net gain of new labor has the full potential of even to outpace the losses of old labor. Competences of persons, people and humans must be developed and developed further, to prevent that labor can be replaced by automation effects or by artificial intelligence (at least not in simple ways). Crucial are here multi-facetted competences, where disciplinary professional knowledge is being augmented and recombined with interdisciplinary and transdisciplinary skills and competences (for this also the metaphors of "T-competences" and "M-competences" are being used). Creativity and creativity skills are crucial in driving innovation, which again is advancing the evolution of knowledge society, knowledge economy and knowledge democracy. Arts and artistic research represent crucial components in an advanced innovation system. Artificial intelligence will not replace human intelligence, but artificial intelligence will complement 
human intelligence. However, also here the challenge is to organize labor (and the economy, society and democracy) in a way, so that human intelligence is using artificial intelligence for the purpose of supporting (and carrying higher) human intelligence and human labor. Therefore, the idea is to speak more of a co-evolution of artificial intelligence and of human intelligence, but where the humans are in the position of control and sovereign decision-making (also expressed in the metaphor of a "Centaur Intelligence"). Artificial intelligence can provide assumptions and guidance, however, the humans are the ones who are making the decisions or who engage in "making the decision-making". There is this understanding that advanced knowledge manifests itself in a diversity of knowledge modes and innovation modes, and that this pluralism of knowledge also requires a political pluralism, which is a characteristic and component clearly of democracy. Democracy as innovation enabler, or the quality of democracy as an innovation enabler, emphasize the connectedness and interconnectedness of (a) knowledge development and of (b) democracy development and democracy evolution. In reference to the example and metaphor of a society of free women and free men in ancient Greece (the democratic polis in Athens), we can speculate, how in Industry 4.0 the artificial intelligence and other advanced technological means could be used and can be used and utilized to carry out the (boring) standard work, whereas persons, people and humans then are focusing more on the interesting work. This we may phrase and paraphrase as a type of Renaissance of (interesting) labor in the Age of Knowledge and Innovation. So what are then the new (and old) forms of entrepreneurship and of creative innovation in Industry 4.0 (or Industry 5.0 in a later phase), what can artificial-intelligence-based entrepreneurship possibly mean? What Industry 4.0 really needs and requires is a Democracy 5.0. If there is art and democracy, we also should think about the art of democracy."

Funding Open access funding provided by Danube University Krems University for Continuing Education.

Open Access This article is licensed under a Creative Commons Attribution 4.0 International License, which permits use, sharing, adaptation, distribution and reproduction in any medium or format, as long as you give appropriate credit to the original author(s) and the source, provide a link to the Creative Commons licence, and indicate if changes were made. The images or other third party material in this article are included in the article's Creative Commons licence, unless indicated otherwise in a credit line to the material. If material is not included in the article's Creative Commons licence and your intended use is not permitted by statutory regulation or exceeds the permitted use, you will need to obtain permission directly from the copyright holder. To view a copy of this licence, visit http://creativecommons.org/ licenses/by/4.0/.

\section{References}

Alavi, M., \& Leidner, D. E. (2001). Knowledge management and knowledge management systems: Conceptual foundations and research issues. MIS quarterly, 107-136.

Ashton, K. (2009). That 'internet of things' thing. RFID journal, 22(7), 97-114. 
Aslam F., Aimin W., Li M., Rehman K. (2020). "Innovation in the era of IoT and industry 5.0: Absolute Innovation Management (AIM) Framework", Information 2020, 11, 124. https://doi.org/10.3390/ info1 1020124

Bag, S., Telukdarie, A., Pretorius, J. H. C., \& Gupta, S. (2018). Industry 4.0 and supply chain sustainability: framework and future research directions. Benchmarking: An International Journal.

Bast, G. (2013). Preparing a "Creative Revolution" - Arts and Universities of the Arts in the Creative Knowledge Economy, 1471-1476, in: Elias G. Carayannis (Editor-in-Chief) / Igor N. Dubina, Norbert Seel, David F. J. Campbell, Dimitri Uzunidis (Associate Editors): Encyclopedia of Creativity, Invention, Innovation and Entrepreneurship. New York, NY: Springer. (http://link.springer.com/referenceworkentry/10.1007/978-14614-3858-8_442 and http://www.springerreference.com/docs/html/chapterdbid/378818.html)

Bast, G., Carayannis, E. G., Campbell D. F. J.(eds.) (2015). Arts, Research, Innovation and Society. New York, NY: Springer. (https://link.springer.com/book/10.1007\%2F978-3-319-09909-5)

Bast, G., Carayannis, E. G., Campbell, David F. J. (eds.) (2019). The future of education and labor. New York, NY: Springer. (https://www.springer.com/gp/book/9783030260675)

Brandenburger, A. M., \& Nalebuff, B. J. (1997). Co-Opetition. Doubleday.

Braganza, A., Brooks, L., Nepelski, D., et al. (2017). Resource management in big data initiatives: processes and dynamic capabilities. Journal of Business Research, 70, 328-337.

Bresciani, S., Ferraris, A., \& Del Giudice, M. (2018). The management of organizational ambidexterity through alliances in a new context of analysis: Internet of Things (IoT) smart city projects. Technological Forecasting and Social Change, 136, 331-338.

Buchanan R. (1992). "Wicked Problems in Design Thinking”, Design Issues, Vol. 8, No. 2, pp. 5-21, the MIT Press

Buhr, D. (2017). Social Innovation Policy for Industry 4.0. Division for Social and Economic Policies.

Burritt, R., \& Christ, K. (2016). Industry 4.0 and environmental accounting: a new revolution? Asian Journal of Sustainability and Social Responsibility, 1(1), 23.

Bush, V. (1945). Science: The endless frontier. Washington, D.C.: United States Government Printing Office. (http://www.nsf.gov/od/lpa/nsf50/vbush1945.htm\#transmittal)

Cai, Y., \& Lattu, A. (2020). Synergy Building between Triple Helix and Quadruple Helix. Tampere, Finland: Faculty of Management and Business, University of Tampere (unpublished manuscript for an article)

Campbell, D. F. J. \& Carayannis, E. G. (2013a). Quality of Democracy and Innovation, 1527-1534, in: Elias G. Carayannis (Editor-in-Chief) / Igor N. Dubina, Norbert Seel, David F. J. Campbell, Dimitri Uzunidis (Associate Editors): Encyclopedia of Creativity, Invention, Innovation and Entrepreneurship. New York, NY: Springer. (http://link.springer.com/referenceworkentry/10.1007\%2F978-1-4614-3858-8_509\# and http://www.springerreference.com/docs/html/chapterdbid/378878.html)

Campbell, D. F. J., \& Carayannis, E. G.(2013b). Epistemic governance in higher education. Quality enhancement of universities for development. SpringerBriefs in Business. New York, NY: Springer. (http://www.springer.com/business+\%26+management/organization/book/978-1-4614-4417-6)

Campbell, D. F. J., \& Carayannis, E. G. (2013c). Epistemic governance and epistemic innovation policy, 697702, in: Elias G. Carayannis (Editor-in-Chief) / Igor N. Dubina, Norbert Seel, David F. J. Campbell, Dimitri Uzunidis (Associate Editors): Encyclopedia of Creativity, Invention, Innovation and Entrepreneurship. New York, NY: Springer. (https://doi.org/10.1007/978-1-4614-3858-8_271 and http://www. springerreference.com/docs/html/chapterdbid/378723.html)

Campbell, D. F. J., Carayannis, E. G., \& Rehman, S. S. (2015). Quadruple helix structures of quality of democracy in innovation systems: the USA, OECD Countries, and EU member countries in global comparison. Journal of the Knowledge Economy 6 (3), 467-493. (http://link.springer.com/ article/10.1007/s13132-015-0246-7)

Campbell, D. F. J., \& Carayannis, E. G. (2016a). Epistemic governance and epistemic innovation policy. Technology, Innovation and Education, 2:2 (pp. 1-15). (https://doi.org/10.1186/s40660-016-0008-2) (http:// technology-innovation-education.springeropen.com/articles/10.1186/s40660-016-0008-2)

Campbell, D. F. J., \& Carayannis, E. G. (2016b). The academic firm: A new design and redesign proposition for entrepreneurship in innovation-driven knowledge economy. Journal of Innovation and Entrepreneurship, 5:12 (pp. 1-10). (https://doi.org/10.1186/s13731-016-0040-1) (http://innovation-entrepreneurship.springeropen.com/articles/10.1186/s13731-016-0040-1)

Campbell, D. F. J. (2019). Global quality of democracy as innovation enabler. Measuring democracy for success. New York, NY: Palgrave Macmillan. (https://doi.org/10.1007/978-3-319-72529-1 and https://www.palgrave.com/de/book/9783319725284) 
Campbell, D. F. J., Carayannis, E. G., \& Bast, G. (2019). Conclusion: The future of the future of education and labor, 245-253, in: Gerald Bast / Elias G. Carayannis / David F. J. Campbell (eds.) (2019). The Future of Education and Labor. New York, NY: Springer. (https://www.springer.com/ $\mathrm{gp} / \mathrm{book} / 9783030260675$ )

Carayannis, E. G., \& Maldifassi, J. (1992). Improving the management of nuclear technology: Technical, financial, and organizational measures for assessing the performance of nuclear utilities. International Journal of Global Energy Issues, 4(3), 125-139.

Carayannis, Elias G. (1994a). The strategic management of technological learning: Transnational decision-making frameworks and their empirical effectiveness. Rensselaer Polytechnic Institute: Dissertation.

Carayannis, Elias G. (1994b). The strategic management of technological learning: Transnational decision-making frameworks and their empirical effectiveness. Dissertation Abstracts International, 55(11), 3564. (UMI No. 9511131)

Carayannis, E. G., \& E.M. Rogers , K. Kurihara , M.M. Allbritton, . (1998). High-technology spin-offs from government R\&D laboratories and research universities. Technovation, 18(1), 1-11.

Carayannis, Elias G. (2001). The Strategic management of technological learning. learning to learn and learning to learn-how-to-learn as drivers of strategic choice and firm performance in global, technologydriven-markets. Boca Raton, Florida: CRC Press.

Carayannis, E. G., \& Gonzalez, E. (2003). Creativity and Innovation = Competitiveness? When, How, and Why, Vol. 1, Chap. 8. In L. V. Shavinina (Ed.), The International Handbook on Innovation (pp. 587-606). Pergamon.

Carayannis, E. G., Gonzalez, E., \& Wetter, J. (2003). The Nature and Dynamics of Discontinuous and Disruptive Innovations From a Learning and Knowledge Management Perspective, Vol. 1, Chap. 4. In L. V. Shavinina (Ed.), The International Handbook on Innovation (pp. 115-138). Pergamon.

Carayannis, E. G. \& Campbell, D. F. J. (2006). "Mode 3": Meaning and Implications from a Knowledge Systems Perspective, 1-25, in: Elias G. Carayannis / David F. J. Campbell (eds.): Knowledge creation, diffusion, and use in innovation networks and knowledge clusters. A Comparative Systems Approach across the United States, Europe and Asia. Westport, Connecticut: Praeger.

Carayannis, E. G., \& Campbell, D. F. J. (2009). "Mode 3" and "Quadruple Helix": Toward a 21st Century Fractal Innovation Ecosystem. International Journal of Technology Management, 46(3/4), 201-234. (http:// www.inderscience.com/browse/index.php?journalID $=27 \& y e a r=2009 \& v o l=46 \&$ issue $=3 / 4$ and http:// www.inderscience.com/search/index.php?action=record\&rec_id=23374\&prevQuery $=\& p s=10 \& \mathrm{~m}=$ or)

Carayannis, E. G. \& Campbell, D. F. J. (2010). Triple helix, quadruple helix and quintuple helix and how do knowledge, innovation and the environment relate to each other? A proposed framework for a trans-disciplinary analysis of sustainable development and social ecology. International Journal of Social Ecology and Sustainable Development, 1(1), 41-69. (https://www.igi-global.com/article/ triple-helix-quadruple-helix-quintuple/41959)

Carayannis, E. G., \& Campbell, D. F. J. (2011). Open Innovation Diplomacy and a 21st Century Fractal Research, Education and Innovation (FREIE) Ecosystem: Building on the Quadruple and Quintuple Helix Innovation Concepts and the "Mode 3" Knowledge Production System. Journal of the Knowledge Economy, 2(3), 327-372.

Carayannis, E. G. \& Campbell, D. F. J. (2012). Mode 3 Knowledge Production in Quadruple Helix Innovation Systems. 21st-Century Democracy, Innovation, and Entrepreneurship for Development. (SpringerBriefs in Business.). New York, NY: Springer. (http://www.springer.com/business+\%26+management/ book/978-1-4614-2061-3 and http://www.springer.com/cda/content/document/cda_downloaddocument/ 9781461420613-c1.pdf?SGWID=0-0-45-1263639-p174250662)

Carayannis, E. G. Barth, T. D., \& Campbell, D. F. J. (2012). The Quintuple Helix Innovation Model: Global Warming as a Challenge and Driver for Innovation. Journal of Innovation and Entrepreneurship, 1(1), 1-12. (http://www.innovation-entrepreneurship.com/content/pdf/2192-5372-1-2.pdf)

Carayannis, E. G., \& Campbell, D. F. J. (2014). Developed Democracies versus Emerging Autocracies: Arts, Democracy, and Innovation in Quadruple Helix Innovation Systems. Journal of Innovation and Entrepreneurship, 3:12. (http://www.innovation-entrepreneurship.com/content/3/1/12)

Carayannis, E. G., \& Pirzadeh, A. (2014). The knowledge of culture and the culture of knowledge. Implications for theory, policy and practice. Houndmills: Palgrave Macmillan. (http://www.amazon.de/TheKnowledge-Culture-Implications-Practice/dp/1403942439/ref=sr_1_1 ?ie=UTF8\&qid=1403080044\& $\mathrm{sr}=8-1 \&$ keywords=carayannis+knowledge + of + culture) 
Carayannis, E. G., \& Campbell, D. F. J. (2015). Art and artistic research in quadruple and quintuple helix innovation systems. In G. Bast \& , Elias G. Carayannis, David F. J. Campbell, (Eds.), Arts, Research, Innovation and Society (pp. 29-51). Springer.

Carayannis, E. G., Hens L., \& Nicolopoulou-Stamati, P. (2017). Trans-disciplinarity and growth. Nature and characteristics of trans-disciplinary training programs on the human-environment interphase. Journal of the Knowledge Economy, 8(1), 1-22.

Carayannis, E. G., Grigoroudisn, E., Campbell, D. F. J., Meissner, D., \& Stamati, D. (2018a). The ecosystem as helix: an exploratory theory-building study of regional co-opetitive entrepreneurial ecosystems as quadruple/quintuple helix innovation models. $R \& D$ Management, 48(1), 148-162. (https:// doi.org/10.1111/radm.12300/full)

Carayannis, E. G., Grigoroudis, E., Campbell, D. F. J., Meissner, D., \& Stamati, D. (2018b). 'Mode 3' universities and academic firms: thinking beyond the box trans-disciplinarity and nonlinear innovation dynamics within coopetitive entrepreneurial ecosystems. International Journal of Technology Management 77(1/2/3), 145-185. (https://doi.org/10.1504/IJTM.2018.091714)

Carayannis, E. G. (2019a). From Industry 4.0 to Industry 5.0 and the quintuple innovation helix framework - Theories, policies and practices. CI Food Webinar Series: Dr. Elias G. Carayannis Event, Teaching by Elias G. Carayannis. (https://www.mcgill.ca/desautels/channels/event/ci-food-webinar-series-drelias-g-carayannis-296951

Carayannis, E. G. (2019b). Innovation ecosystems and artificial intelligence. Teaching by Elias G. Carayannis. (https://www.iem.fraunhofer.de/de/termine/archiv/2019/workshop-innovation-ecosystems-artificialintelligence.html)

Carayannis, E. G. (2019c). Towards Industry and Society 5.0. ICSB Exchange: Fall Series. Teaching by Elias G. Carayannis. (https://www.youtube.com/watch?v=CEPE_vDfyv0)

Carayannis, E. G., \& Campbell, D. F. J. (2019). Smart quintuple helix innovation systems: How social ecology and environmental protection are driving innovation, sustainable development and economic growth. (SpringerBriefs in Business.). New York, NY: Springer. (https://www.springer.com/ de/book/9783030015169)

Carayannis, E. G. (2020). Democracy and the Environment are Endangered Species. RiConfiguring Today for a Better Tomorrow: Theories, Policies, Practices and Politics for Smart Growth. Interview with Dr. Prof. Elias Carayannis by Charlotte Koldbye. (Research Reconfiguring and Innovation Constellations). Brussels: Project with funding from the European Union's Horizon 2020 research and innovation programme under grant agreement No 788047. (http://riconfigure.eu/wpcontent/uploads/2020/01/Interview-with-Elias-Carayannis_2020_Final.pdf)

Carayannis, E. G., \& Campbell, D. F. J. (2020). Triple Helix vs. Quadruple and Quintuple Helix Dialogue. Tampere: Triple Helix Conference 2020. (https://events.tuni.fi/thc2020/updates-from-theconference-sessions/conference-day-1-triple-helix-vs-quadruple-and-quintuple-helix-dialogue/)

Carayannis, E. G., Draper, J., \& Bhaneja, B. (2020). Towards Fusion Energy in the Industry 5.0 and Society 5.0 Context: Call for a Global Commission for Urgent Action on Fusion Energy. Journal of the Knowledge Economy 11(3), 1-14. (https://doi.org/10.1007/s13132-020-00695-5)

Carayannis, E. G., Christodoulou, K., Christodoulou, P., Chatzichristofis, S. A., \& Zinonos, Z. (2021). Known Unknowns in an Era of Technological and Viral Disruptions: Implications for Theory, Policy, and Practice. Journal of the Knowledge Economy, 12(1), 1-24. (https://www.ncbi.nlm.nih.gov/ pmc/articles/PMC7873668/)

Carayannis, E. G., Dezi, L., Gregori, G., \& Calo, E. (2021). Smart Environments and Techno-centric and Human-Centric Innovations for Industry and Society 5.0: A Quintuple Helix Innovation System View Towards Smart, Sustainable, and Inclusive Solutions. Journal of the Knowledge Economy, 12(1), 25-55. (https://www.ncbi.nlm.nih.gov/pmc/articles/PMC7903376/)

Carolan, M. (2017). Publicising food: big data, precision agriculture, and co-experimental techniques of addition: publicising f ood. Sociologia Ruralis, 57, 135-154.

Chandler, D. (2015). A world without causation: big data and the coming of age of posthumanism. Millenn J Int Stud, 43, 833-851.

Danilda, I., Lindberg, M., \& Torstensson, B. M. (2009). Women Resource Centres. A Quattro Helix Innovation System on the European Agenda. Paper. (http://www.hss09.se/own_documents/ Papers/3-11\%20-\%20Danilda\%20Lindberg\%20\&\%20Torstensson\%20-\%20paper.pdf)

Deese, R. S. (2019). Climate change and the future of democracy. Springer.

de Sousa Jabbour, A. B. L., Jabbour, C. J. C., Foropon, C., \& Godinho Filho, M. (2018). When titans meet-Can industry 4.0 revolutionise the environmentally-sustainable manufacturing wave? The role of critical success factors. Technological Forecasting and Social Change, 132, 18-25. 
Dorst, K. (2011). The core of 'design thinking' and its application. Design Studies, 32(6), 521-532. https://doi.org/10.1016/j.destud.2011.07.006

Eigelsreiter, B. (2017). Consumerization of IT, cyber-democracy and cyber-crime: The inherent challenges and opportunities of different ends of a continuum. In G. Elias \& Carayannis, David F. J. Campbell, Marios P. Efthymiopoulos, (Eds.), Handbook of cyber-development, cyber-democracy, and cyber-defense (pp. 565-594). Springer.

Elim H. I., Zhai G. (2020). "Control system of multitasking interactions between Society 5.0 and Industry 5.0: A conceptual introduction \& its applications", Journal of Physics: Conf. Series 1463012035. https://doi.org/10.1088/1742-6596/1463/1/012035

Ellitan L., Anatan L. (2019). “Achieving business continuity in Industrial 4.0 and Society 5.0”, International Journal of Trend in Scientific Research and Development, 4, 2 ISSN: 2456-6470

Etzkowitz, H., \& Leydesdorff, L. (1995). The triple helix-university-industry-government relations: A laboratory for knowledge-based economic development. EASST Review, 14, 14-19.

Etzkowitz, H., \& Leydesdorff, L. (2000). The dynamics of innovation: from national systems and "Mode 2 " to a triple helix of university-industry-government relations. Research Policy, 29, 109-123.

European Commission (2009). The World in 2025. Rising Asia and Socio-Ecological Transition. Brussels: European Commission. (http://ec.europa.eu/research/social-sciences/pdf/the-world-in-2025report_en.pdf)

Fauquex M., Goyal S., Evequoz F., Bocchi Y. (2015). "Creating People-aware IoT Applications by Combining Design Thinking and User-centered Design Methods", Proceedings of the IEEE 2ndWorld Forum on Internet of Things (WF-IoT), Milan, Italy, pp. 57-62.

Ferreira C. M., Serpa S. (2018). "Society 5.0 and Social Development", preprinted article. https://doi. org/10.20944/preprints201811.0108.v1

Fischer-Kowalski, M., \& Haberl, H. (Eds.). (2007). Socioecological transitions and global change. Trajectories of social metabolism and land use. Edward Elgar.

Fukuyama M. (2018). "Society 5.0: Aiming for a new human-centered society", Japan Economic Foundation Journal SPOTLIGHT, July/August 2018.

Galan, M., Campbell, D. F. J., \& Carayannis, E. G. (2018). The Role of Information and Communication Technology (ICT) in the Governance of Energy Access: Exploring Application of Quadruple and Quintuple Helix Innovation Theory in Technology Transfer, 59-85, in: Carayannis, Elias G. / David F. J. Campbell / Marios Panagiotis Efthymiopoulos (eds.): Handbook of Cyber-Development, Cyber-Democracy, and Cyber-Defense. New York, NY: Springer. (https://www.springer. com/de/book/9783319090689 and https://doi.org/10.1007/978-3-319-06091-0)

Gano, G. (2015). Starting with universe: Buckminster Fuller's design science now. Futures, 70, 56-64.

Gehrke L., Kühn A.T., Rule D., Moore P., Bellmann C., Siemes S., Dawood D., Singh L., Kulik J., Standley M. A (2015). "Discussion of Qualifications and Skills in the Factory of the Future: A German and American Perspective". https://www.researchgate.net/publication/279201790

Gibbons, M., Limoges, C., Nowotny, H., Schwartzman, S., Scott, P., \& Trow, M. (1994). The New Production of Knowledge. The Dynamics of Science and Research in Contemporary Societies. London: Sage.

Giusto, D., Iera, A., Morabito, G., \& Atzori, L. (Eds.). (2010). The internet of things: 20th Tyrrhenian workshop on digital communications. Springer Science \& Business Media.

Haller, S., Karnouskos, S., \& Schroth, C. (2008). The internet of things in an enterprise context. In Future Internet Symposium (pp. 14-28). Springer, Berlin, Heidelberg.

Hausberg, J. P., Liere-Netheler, K., Packmohr, S., Pakura, S., \& Vogelsang, K. (2019). Research streams on digital transformation from a holistic business perspective: a systematic literature review and citation network analysis. Journal of Business Economics, 89, 931-963.

Hanusch, F. (2018). Democracy and Climate Change. Routledge.

Hemlin, S., Allwood, C. M., \& Martin, B. R. (2004). Creative knowledge environments. The influences on creativity in research and innovation. Cheltenham: Edward Elgar.

Hermann, M., Pentek, T., \& Otto, B. (2015). Design principles for Industrie 4.0 scenarios: a literature review. Technische Universität Dortmund, Dortmund.

Hofmann, E., \& Rüsch, M. (2017). Industry 4.0 and the current status as well as future prospects on logistics. Computers in Industry, 89, 23-34.

Hollands, R. G. (2008). Will the real smart city please stand up? Intelligent, progressive or entrepreneurial? City, 12(3), 303-320. 
Horváth, D., \& Szabó, R. Z. (2019). Driving forces and barriers of Industry 4.0: Do multinational and small and medium-sized companies have equal opportunities? Technological Forecasting and Social Change, 146, 119-132.

Kagermann, H., Helbig, J., Hellinger, A., \& Wahlster, W. (2013). Recommendations for implementing the strategic initiative INDUSTRIE 4.0: Securing the future of German manufacturing industry; final report of the Industrie 4.0 Working Group. Forschungsunion.

Kamble, S. S., Gunasekaran, A., \& Sharma, R. (2018). Analysis of the driving and dependence power of barriers to adopt industry 4.0 in Indian manufacturing industry. Computers in Industry, 101, $107-119$.

Kuhn, T. S. (1962). The structure of scientific revolutions. The University of Chicago Press.

Lake, R. W. (2017). Big Data, urban governance, and the ontological politics of hyperindividualism. Big Data Soc, 4, 205395171668253.

Lee, I., \& Lee, K. (2015). The Internet of Things (IoT): Applications, investments, and challenges for enterprises. Business Horizons, 58(4), 431-440.

Leydesdorff, L., \& Etzkowitz, H. (1998). The triple helix as a model for innovation studies. Science and Public Policy, 25(3), 195-203.

Leydesdorff, L., \& Etzkowitz, H. (2003). Can 'The public' be considered as a fourth helix in universityindustry-government relations? Report on the Fourth Triple Helix Conference, 2002. Science and Public Policy, 30(1), 55-61.

Leydesdorff, L. (2012). The Triple Helix, Quadruple Helix, ..., and an N-Tuple of Helices: Explanatory Models for Analyzing the Knowledge-Based Economy? Journal of the Knowledge Economy, 3(1), 25-35. (https://doi.org/10.1007/s13132-011-0049-4)

Liao, Y., Deschamps, F., Loures, E. D. F. R., \& Ramos, L. F. P. (2017). Past, present and future of Industry 4.0-a systematic literature review and research agenda proposal. International journal of production research, 55(12), 3609-3629.

Lorenz M., Rüßmann M., Strack R., Lueth K., Bolle M. (2015). "Man and Machine in Industry 4.0. How Will Technology Transform the Industrial Workforce Through 2025?". https://www.bcg. com/publications/2015/technology-businesstransformation-engineered-products-infrastructureman-machineindustry-4.aspx

Latour, B., \& Weibel, P. (2002). ICONOCLASH: Beyond the image wars in science, religion and art. MIT Press.

Madsen, A. K., Flyverbom, M., Hilbert, M., \& Ruppert, E. (2016). Big data: issues for an international political sociology of data practices: table 1. International Political Sociology, 10, 275-296.

Martínez-Caro, E., Cegarra-Navarro, J. G., García-Pérez, A., \& Fait, M. (2018). Healthcare service evolution towards the Internet of Things: An end-user perspective. Technological Forecasting and Social Change, 136, 268-276.

Mitterlehner, B. (2014). Cyber-Democracy and Cybercrime: Two Sides of the Same Coin, 207-230, in: Elias G. Carayannis / David F. J. Campbell / Marios P. Efthymiopoulos (eds.): Cyber-development, cyber-democracy and cyber-defense. Challenges, Opportunities And Implications For Theory, Policy And Practice. New York, NY: Springer.

Morakanyane R, Grace A, O'Reilly P (2017). Conceptualizing digital transformation in business organizations: A systematic review of literature. In: Proceedings of the 30th bled eConference, pp 427-443.

Müller, J. M., Kiel, D., \& Voigt, K. I. (2018). What drives the implementation of Industry 4.0? The role of opportunities and challenges in the context of sustainability. Sustainability, 10(1), 247.

Nahavandi S. (2019). "Industry 5.0-A Human-Centric Solution”, Sustainability, 11, 4371. https://doi. org/10.3390/su11164371

Nambisan, S., Wright, M., \& Feldman, M. (2019). The digital transformation of innovation and entrepreneur- ship: progress, challenges and key themes. Research Policy, 48, 103773.

Nowotny, H., Scott, P., \& Gibbons, M. (2001). Re-thinking science. Knowledge and the public in an age of uncertainty. Cambridge: Polity Press.

Nowotny, H., Scott, P., \& Gibbons, M. (2003). Mode 2 revisited: The new production of knowledge. Minerva, 41, 179-194.

Nowotny, H. Scott, P., \& Gibbons, M. (2006). Re-Thinking Science: Mode 2 in Societal Context, 39-51, in: Elias G. Carayannis / David F. J. Campbell (eds.): Knowledge creation, diffusion, and use in innovation networks and knowledge clusters. A comparative systems approach across the United States, Europe and Asia. Westport, Connecticut: Praeger. 
Ng, I. C., \& Wakenshaw, S. Y. (2017). The Internet-of-Things: Review and research directions. International Journal of Research in Marketing, 34(1), 3-21.

OECD. (2005). “Oslo Manual-Guidelines for Collecting and Interpreting Innovation Data”, Organization for Economic Cooperation and Development (OECD): Paris, France (p. 2005). Brussels, Belgium.

Onday O. (2019). "Japan's Society 5.0: Going Beyond Industry 4.0”, Business and Economic Journal, 10: 389. https://doi.org/10.4172/2151-6219.1000389

Ozdemir V., Hekim N. (2018). "Birth of Industry 5.0: Making Sense of Big Data with Artificial Intelligence, 'The Internet of Things' and Next-Generation Technology Policy”, Journal of Integrative Biology, 22, 1. https://doi.org/10.1089/omi.2017.0194

Park, Han Woo (2014). Transition from the Triple Helix to N-Tuple Helices? An interview with Elias G. Carayannis and David F. J. Campbell. Scientometrics 99(1), 203-207. (http://link. springer.com/article/10.1007\%2Fs11192-013-1124-3 and http://download.springer.com/ static/pdf/907/art\%253A10.1007\%252Fs11192-013-1124-3.pdf?auth66=1397308723_ 4cb0003877af5305d5dc202280b9cd6d\&ext=.pdf)

Pashek D., Mocan A., Draghici A. (2019). "Industry 5.0 - The Expected Impact of next Industrial Revolution", Management, Knowledge and Learning International Conference 2019

Pasisi J., Gibb J., Matthews J. H. (2014). "Approaching wicked problems through design thinking", Proceedings of the 28th Australian and New Zealand Academy of Management Conference: Reshaping Management for Impact, Sydney, Australia

Pereira A., Santos F. C., Lima T. M. (2020). "Industry 4.0 and Society 5.0: Opportunities and threats", International Journal of Recent Technology and Engineering (IJRTE) ISSN: 2277-3878, Volume-8 Issue-5

Piccarozzi, M., Aquilani, B., \& Gatti, C. (2018). Industry 4.0 in management studies: A systematic literature review. Sustainability, 10(10), 3821.

Polanyi, M. (1962). The Republic of Science: Its Political and Economic Theory. Minerva 1, 54-74. (http://sciencepolicy.colorado.edu/students/envs_5100/polanyi_1967.pdf and http://fiesta.bren. ucsb.edu/ gsd/595e/docs/41.\%20Polanyi_Republic_of_Science.pdf)

Riesener M., Dolle C., Kuhn M. (2019), "Innovation Ecosystems for Industrial Sustainability", Procedia Computer Science, $26^{\text {th }}$ CIRP Life Cycle Engineering (LCE) Conference. https://doi.org/10. 1016/j.procir.2019.01.035

Rothe, D. (2017). Seeing like a satellite: remote sensing and the ontological politics of environmental security. Secur Dialogue, 48, 334-353.

Salgues B. (2018). Society 5.0. Industry of the Future, Technologies, Methods and Tools, ISTE - John Wiley \& Sons, Hoboken (NJ) - London

Schallmo, D., Williams, C. A., \& Boardman, L. (2017). Digital transformation of business modelsbest practice, enablers, and roadmap. International Journal of Innovation Management, 21, 1740014.

Skobelev P. O., Borovik S. Y. (2017), "On the Way from Industry 4.0 to Industry 5.0: From Digital Manufacturing to Digital Society”, International Scientific Journal, Web ISSN: 2534-997x; Print ISSN: $2543-8582$

Stacey, R. D., Gri, D., \& Shaw, P. (2000). Complexity and management: Fad or radical challenge to systems thinking? Psychology Press.

Taratukhin V., Yadgarova Y., Becker J. (2018). "The Internet of things prototyping platform under the design thinking methodology", Proceedings of the ASEE Annual Conference \& Exposition, Salt Lake City, UT.

Urbinati, A., Chiaroni, D., Chiesa, V., Frattini, V. (2018). The role of digital technologies in open innovation processes: an exploratory multiple case study analysis, R\&D Management.

Vitali I., Arquilla V., Tolino U. (2017). "A Design Perspective for IoT Products. A case study of the design of a smart product and a smart company following a crowdfunding campaign", The Design Journal 20:sup1, S2592-S2604. https://doi.org/10.1080/14606925.2017.1352770

Vittikh, V. A. (2014). Evolution of ideas on management processes in the society: From cybernetics to evergetics. Group Decision and Negotiation, 24, 825-832. https://doi.org/10.1007/s10726-014-9414-6

Von Hippel, E. (1995). The sources of innovation. Oxford University Press.

Von Hippel, E. (2005). Democratizing innovation. Cambridge, Massachusetts: The MIT Press. (https:// web.mit.edu/evhippel/www/books/DI/DemocInn.pdf) 
Walch M., Karagiannis D. (2019). "How to Connect Design Thinking and Cyber-physical Systems: The s* IoT Conceptual Modelling Approach”, Proceedings of the 52nd Hawaii International Conference on System Sciences, Maui, HI, USA.

Yousefikhah, S. (2017). "Sociology of Innovation: Social Construction of Technology Perspective", $A D$ Minister, 31-43. https://doi.org/10.17230/ad-minister.30.2

Zahra, S. A., \& George, G. (2002). Absorptive capacity: A review, reconceptualization, and extension. Academy of Management Review, 27(2), 185-203.

Publisher's Note Springer Nature remains neutral with regard to jurisdictional claims in published maps and institutional affiliations.

\section{Authors and Affiliations}

\section{Elias G. Carayannis ${ }^{1}$ - David F. J. Campbell $2,3,4$}

Elias G. Carayannis

caraye@gwu.edu

1 Science, Technology, Innovation and Entreprneurship, European Union Research Center, GWU School of Business, The George Washington University, Washington, DC, USA

2 Department for Higher Education Research, Danube University Krems, Krems, Austria

3 Department of Political Science, University of Vienna, Universitätsstrasse 7, 1010 Vienna, Austria

4 Department of Science Communication and Higher Education Research, Research Associate, Alpen-Adria-University, Klagenfurt, Austria 